\title{
Ayıran Duvarlar, Dönüşen Sandıklar: Kapalı Konut Siteleri ve Seçim Sonuçlarına Etkileri
}

\author{
Burak Özer" \& Burcu Taşkın*
}

\section{Öz}

Türkiye'de toplumdaki sosyo-ekonomik farklılıklar son dönemlerde özellikle İstanbul ilinde gittikçe yaygınlaşan konut siteleri üzerinden somutlaşmış ve mekân-sınıf iliş̧kisini görselleştirmiş̧tir. Konut sahiplerinin sayısı on binleri bulan bu sitelerin yarattığı nüfus hareketliliği seçim sonuçlarını nasıl etkilemektedir? Kentsel alanlarda son yıllarda giderek artış gösteren kapalı konutların bulundukları bölgenin seçim sonuçlarına etkisini anlamayı amaçlayan bu çalışma, oy verme davranışlarını mekân-refah ilişkisi açısından değerlendirerek literatürdeki boşluğu doldurmaktadır. İstanbul Tuzla ilçesindeki kapalı konut sitelerini, oluşturdukları nüfus hareketliliğini ve seçim sonuçlarına yansımasını oy verme teorileri üzerinden inceleyen bu çalışma, belirli bir ekonomik düzeyi olan, belirli bir sosyal statüye sahip, bir arada yaşayan seçmen ile aynı coğrafi sınıflar içerisinde yaşayan ancak duvarın öteki tarafında bulunan seçmenin tercihinde büyük farklılıklar olduğunu, toplu konutların yapıldığı bölgenin 2018 genel ve 2019 yerel seçim sonuçlarına etkisi olduğunu ortaya koymuştur. Site sonrasındaki seçimlerde AK P̧arti'nin oyları önemli oranda düşmüş, yine de kayan oyların belli bir bölümü Cumhur İttifakı içinde tutulmuştur. Türkiye ortalamasına göre site seçmenlerinden muhalefet bloğu Millet İttifakı'na giden oylarda önemli bir artış bulunmaktadır. Site sonrasındaki seçmen artışı değerlendirildiğinde merkez-sağ ve merkez-sol partilerin oylarında artış görülürken, yeni oylardan en fazla pay alan partinin iYi Parti olması dikkat çekicidir.

Anahtar Kelimeler: Seçmen Davranışı, Kapalı-Konut Siteleri, Sosyal Sınıf, 2018 Genel seçim, 2019 Yerel seçim.

\section{Dividing Walls, Changing Ballot Boxes: Closed Housing Sites and Their Effects on Election Results}

\section{Abstract}

Social differences embodied in the recent period out of housing sites that are becoming increasingly common, especially in the provinces of Istanbul in Turkey and visualize the spatial-class relations. How the population mobility created by these housing units that inhabited ten thousand residents affect the election results? This study, which aims to understand the effect of the closed housing which has been increasing in urban areas in recent years on the election results, fills the gap in the literature by evaluating the voting behaviour in terms of space-class relationship. This study examines the closed housing estates in Tuzla district of Istanbul, their population mobility and their reflection on the election results based on the voting behaviour theories. Our research revealed that there are great differences between the housing residents and settled neighbourhood that remains outside the walls in terms of party preferences, and the new housings make a block impact on the 2018 parliamentary and 2019 municipality election results. In the elections after the establishment of housings, the votes of the AK Party decreased significantly, however, a certain part of the floating votes were kept within the People's Alliance. Regarding Turkey's average, there is a significant increase in the votes of the opposition bloc Nation Alliance from the voters of the site. When the voter increase after the site is evaluated, it is noteworthy that the votes of the centre-right and centreleft parties increased, while the party with the highest share from the new votes was registered as the IYI Party.

Keywords: Voting Behaviour, Closed-Housing, Social Class, 2018 Turkish parliamentary elections, 2019 Turkish local elections.

"Doktora Öğrencisi | İstanbul Medeniyet Üniversitesi, Sosyal Bilimler Enstitüsü burakozer1666@gmail.com | ORCID: 00000-0003-4300-0126 | DOI: 10.36484/liberal.818092 "Dr. Öğr. Üyesi | İstanbul Medeniyet Üniversitesi, Siyasal Bilgiler Fakültesi burcu.taskin@medeniyet.edu.tr | ORCID: 0000-0003-4504-2098 | DOI: 10.36484/liberal.818092 Liberal Düşünce Dergisi, Yıl: 25, Sayı: 100, Güz 2020, ss. 137-167. Gönderim Tarihi: 1 Eylül 2020 | Kabul Tarihi: 3 Kasım 2020 


\section{Giriş}

Toplumsal grupların siyasi tercihlerinde ve davranışlarında nasıl ve neden farklılık gösterdikleri, siyasal sistemin nasıl çalıştığını anlamak için çok önemli bir yer tutar. Oy verme davranışı bir seçim davranışı olarak son dönemlerde hem siyaset bilimcilerin hem de karar-vericilerin seçmenlerin yerleşik veya değişen tercihleri anlamak ve değerlendirmek için yöneldiği önemli bir olgu haline gelmiştir. Özellikle siyasi partilerin kampanyalarından, aday belirlenmesine; söylemlerinden eylemlerine seçmenleri anlaması ve etkilemesi bağlamında bilimsel yaklaşımlar önem kazanmıştır. Sadece siyasal partinin davranışlarını değil seçmenlerin siyasi tercihlerini ve davranışlarını etkileyen birçok faktör bulunmaktadır. Bu doğrultuda özellikle 1960'lardaki davranışçı kuram (behaviouralism) ile birlikte seçmen davranışlarını anlamaya yönelik birtakım teoriler ve modeller geliştirilmiştir. Bu teoriler ekonomik oy vermeden stratejik oy vermeye (Şikago ekolü); akılcı (rasyonel) oy vermeden etnik, dini, sinıfsal yani sosyolojik oy vermeye (Kolombia ekolü); parti özdeşleşmesinden (Michigan ekolü) hâkim partiye/ideolojiye oy vermeye kadar sıralanmaktadır. Sosyal bilimciler, özellikle sınıf bölünmesi için sosyal gruplar ve parti tercihi arasındaki ilişkiyi ülkeleri karşılaştırarak, uzun süreli incelemişlerdir (örneğin, Franklin, Mackie ve Valen 1992; Knutsen 2006). Soğuk Savaşın sona ermesine, Avrupa Birliği’nin eski sosyalist ülkelere yönelik genişlemesine, bunun yanında işçi-sınıfının büyüklüğünün azalmasına bağlı olarak sınıf-temelli oy vermenin sona erdiği veya bulanıklaştığı argümanları ön plana çıkmıştır (Evans, 1999; Franklin, 1978). Ancak, sınıf bölünmesi, Donald Trump'ın ABD Başkanı seçilmesi ve Brexit süreci ile son zamanlarda hem akademinin içinde hem de dişında yeniden ilgi çekmeye başlamıştır ve demokratik sınıf mücadelesinin bir ifadesi olarak bile tanımlanmaktadır (Evans ve Tilley 2017, 201; Inglehart ve Norris, 2019).

Türkiye'de seçmen davranış analizleri genel itibariyle Batı toplumlarına göre daha farklı toplumsal ayrışmalar (social cleavages) göstermekte ve siyaset bilimi literatüründeki varsayımlarla tam olarak örtüşmemektedir. $\mathrm{Bu}$ yüzden de Batı toplumlarında tarihsel sınıf ayrımlarına ve çatışmalarına dayanan parti özdeşleşmesi ve ideolojik oy verme yaklaşımları, Türkiye'deki incelemelerde çoğu zaman tezat teşkil etmektedir (Çarkoğlu, 2012: 160). Türkiye'deki çalışmalar göstermiştir ki şehirde yaşayan, gelir seviyesi ve gelir durumu daha yüksek olan seçmenler merkez-sol partileri tercih ederken, işçi-sınıfı ve kırsal alanda yaşayan seçmen tercihini ağırlıklı olarak merkez-sağ partilerden, hatta zamanla aşırı-sağ partilerden yana kullanmıştır (Ergüder, 2000; Çarkoğlu, 2012). Diğer yandan 1950’lerde DP, 1990'larda ANAP ve DYP 
ve 2000’lerde AK Parti liberal politikaları izleyerek üst ve orta-üst sınıf seçmeni mobilize etmeyi başarmıştır. Diğer bir deyişle oy verme davranışlarını anlamada genel olarak sınıf temelli açıklamaların yetersiz kaldığı görüşü mevcuttur (Akgün, 2015: 83). Bu yaklaşımda Türkiye siyasetinde “sol”"un eksikliğinin ve/veya tarihsel süreç içinde bastırılmasının, hatta çok geniş mezhepli olmasının etkisi olduğu düşünülebilir (Bora, 2017: 573). Buna karşın sınıf çatışmasının sadece klasik Marksizm bağlamında orta sınıf - işçi sınıfı ayrımına dayanması gerekmemektedir. Sınıf kavramı mavi yaka- beyaz yaka gibi meslek gruplarına göre tanımlanacağı gibi, bazen gelir seviyesine, bazen eğitim seviyesi ve sosyo-ekonomik statüye göre de kategorileştirilebilir. Türkiye'de siyasi partilerin seçmenleri sınıf-temelli olarak mobilize etmedeki başarısı tartışılsa da, partilerin seçim bilgilerindeki emek-sermaye ifadeleri üzerine yapılan analizler partilerin sol-sağ ideolojik yelpazesindeki yerlerine göre söylemler kullandığını gösterir (Dikici-Bilgin, 2018: 185). Bu durum seçmenlerin ideolojik duruşları ile oy verdikleri partilerin söylemlerinin örtüştüğünü belirtir. Toplumdaki tarihsel seküler- İslamcı çatışması, merkez-çevre ile değil, sol-sağ ayrışması ile daha çok örtüşmektedir.

Yine de Batı toplumlarındaki siyasi partilerin toplumsal kökenlerinden farklı bir seçmen-parti ilişkisi sunan Türkiye siyasetinde, seçim sonuçları değerlendirmeleri "sınıf temelli" olarak açıklanmak yerine çoğunlukla akılc1-tercih (rational-choice) teorisine dayanan ekonomik oy verme modeli veya merkez-çevre gerilimi argümanı üzerinden ele alınır. Akılcı-tercih modelinin dayandığı klasik ekonomi teorisine göre seçmenler, siyasal iktidarların mevcut ve geçmiş dönemde sergiledikleri performansı değerlendirerek kendilerine en üst seviyede fayda sağlayacak partiye oy vermektedir. (Çinko, 2006: 105). Bu yaklaşım seçmenlerin mevcut gündeme göre oy verdiğini ön gören diğer kısa-dönemli oy verme davranış modeli ile uyumludur. Bununla birlikte bu modele göre seçmen bir parti ile özdeşleşip her zaman aynı partiye oy vermek yerine stratejik oy kullanabilmekte, bazen de kendisini yakın hissettiği lider ya da partiden ziyade, iktidardaki partinin etkisini azaltacak partiye oy verebilmektedir. Yine partilerin belirlediği adaylar, liderin karizması ve partilerin güncel konulara yaklaşımları seçmenlerin oy verme davranışını etkileyebilmektedir. Seçmenlerin parti tercihlerindeki bu keskin değişimlerin daha çok ekonomik kriz dönemleri ile örtüşmesi "ekonomik oy verme" modelini ön plana çıkarmıştır.

Diğer bir sebep ise, 1970-1980 yılları arasında kırdan kentlere yönelen göçlerin artması ile birlikte kentlerdeki demografik yapının değişmesi, bununla birlikte küresel anlamda yaşanan gelişimler, ulusal anlamda çalışma oranlarının ve eğitim seviyesinin artması, kadınların sosyal hayat içerisinde 
etkinliğinin artması, kuşaksal farkın oluşması, oy verme davranışını hızlı bir şekilde değiştirmiştir. Seçmen davranış analizleri açısından bakarsak 1980’lere kadar bu alanda Türkiye'de sayılı çalışma varken (Ergüder, 1980), günümüzde hem kalitatif hem de kantitatif çalışmalar göze çarpmaktadır. Türk toplumundaki bu hızlı toplumsal dönüşüm ve oy verme davranışındaki değişimler sonucu 1950'lerden 2000'lere parti sistemi, iki partili sistemden (1950-1960), llımlı çok-partili sisteme (1961-1980), hâkim partili çok-partili sistemden (1983-1991), atomik parti sistemine (1991-2002) evrilmiştir (Sayarı, 2002). Parti sistemindeki bu değişimlerin yanı sıra merkez partiler oy kaybetmiş ve aşırı-sağ partiler seçmenlerden daha yaygın destek bulmuştur (Çarkoğlu 1998: 552-553; Ergüder 1995: 71).

$\mathrm{Bu}$ önemli analizlerde seçmen davranışları genellikle geleneksel merkez-çevre gerilimi üzerinden değerlendirilmiş, ekonomik ve ideolojik oy verme modelleri üzerinden tercih değişimleri yorumlanırken, sosyal sinıf temelli açıklamalar düşünülmemiştir. Türkiye'de kentleşmenin artması ile birlikte, özellikle son yıllarda büyükşehirlerde kentsel dönüşüm ile birlikte yaşanan değişimler sonucunda duvarları çevrili, nüfus sayısı olarak fazla ancak çevresiyle çok bağlantısı olmayan lüks, kapalı-konut sitelerinin yükseldiği görülmektedir. Bu sitelerde oturan seçmenlerin ekonomik olarak belirli bir düzeye, statü olarak da orta-üst veya üst sınıfa mensup oldukları söylenebilir. Adeta mahallelerde yeni bir şehir olarak ortaya çıkan siteler, sayısal olarak fazla oldukları için bulundukları bölgenin seçim sonuçlarını da etkiyebilmektedir. Sınıf-temelli oy verme teorilerine göre sınıflar farklı siyasi değerlere sahiptir ve bu onların parti tercihlerini etkiler. Bu teorilere göre birbirlerine sosyo-ekonomik statü olarak benzerlik gösteren kişilerin oy verme davranışlarının da birbirine benzemesi beklenmektedir. Literatürdeki birçok eser, sınıfın değerler üzerindeki etkisini incelerken, bu mekanizmanın sınıf ve siyasi tercihlerle ilgili önemini ölçen birkaç ampirik çalışma vardır. Dolayısıyla bu makaledeki ilk araştırma sorusu: Siyasi değerler sınıf ve parti tercihi arasındaki ilişkiyi ne ölçüde açıklamaktadır? Binlerce konutun ve seçmenin bulunduğu toplu yaşam alanlarından benzer oy tercihleri gözlemlenmektedir. Mahalle yapıları açısından önemli nüfus hareketliliğini getiren kapalı-konut siteler, seçim sonuçlarını nasıl etkilemektedir? Türkiye siyasetinde tarihsel olarak kişilerin sosyo-ekonomik statüsü (gelir ve eğitim seviyesi) yükseldikçe, merkez partilere oy verme oranının arttığı gözlemlenmiştir. Dolayısıyla bu araştırma birbiri ile ilişkili dört argüman öne sürer: 1.Yakın coğrafya veya mahallede yaşayan, yakın sosyal sınıfa ait kişiler benzer seçmen tercihlerinde bulunurlar; 2.Yeni ortaya çıkan toplu-konutlar ve değişen seçmen profili seçim sonuçlarını etkilemektedir; 3.AK Parti kendinden önceki muhafazakar partilere 
göre üst ve orta-üst seçmene daha cazip gelirken, 2012 senesi itibariyle bu oylarda düşüş gözlemlenmektedir. 4.Kentsel dönüşüm projesi ile oluşan toplu-konutlar, yerleşen seçmenlerin sosyo-ekonomik statüsü düşünüldüğünde muhafazakâr iktidar partisinin oylarının düşmesine yol açmaktadır.

Bu ilişkiyi incelemek amacıyla bu çalışmada öncelikli toplumsal tabakalaşma ile siyasi değerler ilişkisini inceleyen teoriler tanımlanacak, ikinci bölümde Türkiye özelinde sinıf/gelir-temelli oy verme modeline odaklanarak genel oy verme davranışları irdelenecektir. Makalenin ana argümanının ve analizinin içerdiği üçüncü bölüm oy verme davranışı bağlamında kapalı-konut sitelerinin tercihlerinin 2018 Cumhurbaşkanlığı, 2018 milletvekili ve 2019 belediye seçim sonuçlarına etkilerinin değerlendirmesini verecektir. Bu bölümde vaka olarak İstanbul/Tuzla'da yaklaşık 4.500 konuttan ve 15.000 seçmenden oluşan bir toplu konutun seçmen davranışı analizi yapılacaktır.

\section{Sınıf ve Sınıf Temelli Oy Verme}

1990'larda Sovyetler Birliği'nin dağılması, Berlin Duvarı'nın yıkılması ve genel olarak liberalizmin sosyalizme hâkim gelmesi ile birlikte, sınıf siyasetinin gerilemeye başladığı düşünülürken, 2007-2008 küresel mali krizi sonrasında birçok Avrupa toplumunda radikal sağ partilerin ortaya çıkması ve özellikle son zamanlarda Britanya'daki Brexit süreci ve ABD’de Trump'ın Başkan seçilmesi, siyaseti anlamada "sınıf analizlerinin" önemini tekrar ortaya çıkarmıştır. Bu noktada sınıf ayrımlarının belirsizleştiğini varsayımına dayanarak, sınıf temelli oy verme eğiliminin zayıflayan bir seviyede ilerlediğini sorgulayan araştırmaların yanı sıra (Dalton, 2008:156; Clarke \& Lipset, 2001:2); sınıflara göre oy vermenin sabit kaldığını veya evrildiğini belirten önemli çalışmalar da mevcuttur (Evans, 1999).

Sınıf temelli oy verme, açık ifade ile belirli bir sosyal sınıftaki insanlar için diğer sınıflardaki seçmenle kıyaslandığında belirli bir siyasi parti veya adaya oy verme eğilimini ifade eder. Sosyolojik olarak sosyal sınıf tarihsel süreç içerisinde sıklıkla üzerinde durulan bir kavram olmuştur. Ancak kavramı tanımlamada ortak bir ifadenin olmadığı da ortadadır. Bazıları için sınıf sosyal statü hiyerarşisi içinde ortak konuma sahip kişiler kategorisini anlatırken; diğerleri için sınıflar güç yapısı içinde birbirleri ile çatışan grupları ifade eder (Wright, 1979: 5-6). Karl Marx’a göre sınıf farklılıkları ve sınıf çatışmaları üretim araçlarına bağlı olarak tarih boyunca mevcut olup değişiklik gösterse de, Weberci gelenek "sınıf” kavramını piyasa ekonomisinin var olması koşuluna bağlamıştır, diğer bir deyişle sınıf ortak ekonomik "yaşam şanslarına” sahip insan topluluğudur (Giddens, 2012). Sosyologlar, insanlar 
ve topluluklar arasındaki eşitsizlikleri açıklamak amacıyla toplumsal tabakalaşmadan söz etmektedirler. Bu tabakalaşma veya gruplaşma her zaman sınıf farklılıklarını tanımlamayabilir, çoğu zaman siyaset biliminde toplumsal ayrışmalar (cleavage) seçmen davranışlarını açıklamada daha çok kullanılır. Toplumsal-kültürel bölünmeler içerisinde cinsiyete göre kadın-erkek; yerleşim yeri ve tarzına göre kırsal-kent; yaşa göre; kimlik temelli dinsel, mezhepsel, ulusal ve etnik ayırımları yer alır. Siyasal bölünmeler yönetici sınıf ve yönetilenler ayrımını, elit-kitle; devlet-halk ayrışmalarını; son olarak ideolojik ve parti temelli farklılıkları içerir. Bunun yanında Siyaset Bilimi ve Sosyoloji disiplininde sınıf konumunun karakteristikleri çok sayıda farklı objektif ve sübjektif kimliği içerebilir: mesleki sınıflandırma, mülkiyet sahipliği; istihdam durumu (örn. mal sahibi ve işçi/memur), statü sıralamaları, gelir düzeyi, eğitim düzeyi, çeşitli eğitim ve gelir kombinasyonları gibi. Örneğin, Oesch'e göre (2006) 8 farklı sınıf kategorisi vardır. Bu şemaya göre sosyo-ekonomik kaynaklara erişimdeki farklılıklar ekonomik; eğitim seviyesindeki farklılıklar kültürel bölünmeyi yaratır. Bu sınıfsal ayrışmalar parti tercihlerinde etkilidir.

Weberci çizgide olan Giddens’a göre (2012:340) iş gücüyle birlikte ortaya çıkan zenginlerin mülkiyeti sınıf ayrımının ana temelini oluşturmaktadır. S1nıf dört temel yönüyle tabakalaşmadan ayrılmaktadır. Birincisi sınıf düzenleri değişkendir. Yani sınıflar arası geçiş mümkündür. İkincisi tabakalaşmanın bazı biçimleri gibi doğumla birlikte gelmemektedir. Toplumsal ve bireysel ekonomik değişiklikler ile birlikte yukarı doğru veya aşağı doğru geçişler mümkündür. Üçüncüsü ve en önemlisi sınıf, ekonomik temellidir. Birey grupları arasındaki ekonomik ayrımlara dayanmaktadır. Dördüncüsü ise, sınıf düzenleri büyük çaptadır ve kişisel değildir. Bundan dolayı da sınıf düzenleri kişisel olmayan birlikler aracılığı ile işlemektedir (Giddens, 2012: 344-345).

Bu ekonomi ve istihdama dayalı değerlendirmelere ek olarak tüketim ögeleri ve yaşam tarzları gibi kültürel faktörlerin de göz önüne alınması gerektiği yine sosyologlar tarafından belirtilmiştir. Fransız sosyolog Pierre Bourdieu, yaşam tarzı tercihinin sınıfın önemli bir belirteni olduğu yaklaşımını desteklemektedir. Mülk, zenginlik gibi materyal mallardan oluşan ekonomik kapitalin önemli olduğunu vurgulayan Bourdieu, bunların sınıfın önemli ortak yanını oluşturduğunu belirtmektedir. Buna ek olarak Bourdieu, sosyal ilişkilerde sınıf çözümlemesin de etkili olduğunu söylemektedir (Grusky, 2008:17). Nitekim bu çalışmanın konusunu oluşturan kapalı-konut siteleri Bourdieu'nun sınıfı oluşturan temel özelliğin benzer yaşam şartları olduğu düşüncesini desteklemektedir. İnsanlar ya da ekonomik olarak belirli sınıfa ait olduğunu düşünen topluluklar ile benzer yerlerde yaşama isteği bu kapalı 
konut sitelerinde ortaya çıkmaktadır. Dolayısıyla, bu araştırmada sınıf tanımı meslek gruplarını değil, gelir seviyesi benzer ve aynı mekânda ikame eden insan topluluğunu ifade etmektedir.

Bu noktada diğer soru sınıfsal özellikler ile oy verme davranışı arasındaki ilişkidir. Sosyal gruplar ve oy verme arasındaki ilişkinin en önemli açıklamaları, bu ilişkinin sosyal grupların farklı değerlerinden kaynaklandığını varsayar. Michigan Okulu, sosyal-yapısal değişkenlerin siyasi tutumlar ve partizan kimliği gibi sosyal-psikolojik nitelikleri etkilediğini ve daha sonra oy seçimini etkilediğini ifade etmektedir (Cambell ve ark. 1960). Bu tanım, sosyal yapının insanların çıkarlarını ve değerlerini etkilediğini iddia eden Lipset ve Rokkan'ın (1967) öncü çalışmasında ifade edilen görüşe benzer. $\mathrm{Bu}$ ilişki daha yeni araştırmalarda da baskındır. Örneğin Evans ve De Graaf $(2013,16)$ sınıf-parti seçim ilişkisinin ekonomik sol-sağ ideoloji boyutundaki seçmenlerin tutumları aracılığıyla açıklanabileceğini varsaymaktadır. Diğer bir deyişle, sınıf temelli oy vermenin etkisi toplumdaki kutuplaşma seviyesi ve parti sistemindeki sol-sağ ayrışmaları ile ilgilidir.

Siyasi değerlerin bir parti ve seçmen için sınıf-temelli davranışları etkilemesi için, sınıfların siyasi değerlerinde farklılıkların olması ve partilerin bu siyasi değerler üzerinden sinyaller göndermesi gerekmektedir. Mutlak bir sınıf-temelli oy vermede işçi sınıfının sol eğilimli işçi partisi veya sosyal-demokrat partiye, orta-sınıfın da merkezdeki liberal partilere veya daha sağında yer alan muhafazakâr partilere oy vermesi beklenmektedir. Günümüzdeki Batı toplumlarında bu mutlak ilişki zayıflamıştır. Best'in (2011) 8 Avrupa demokrasisini karşılaştırdığı çalışmasına göre bunun nedeni bireylerin gruplarla özdeşleşmesinin azalmasıdır. Evans ve Tilly’e göre 1990'larda sınıf-temelli oy vermenin etkisinin azalmasının nedeni düşünüldüğü gibi sınıf farklılıklarının azalması değil, daha çok seçmenin oyuna talip olan partilerin ağırlıklı olarak merkeze kayması ve benzer ekonomi politikaları öne sürmesinden kaynaklanmaktadır.

Çalışmamıza göre modernleşme sürecinden hızlıca geçen Türk toplumunda sınıf çatışmaları değişse de, sınıf-temelli oy verme davranışı çoğu zaman geleneksel seküler- İslamcı ayrımı çerçevesinde devam etmektedir. Diğer yandan, seçmenlerin sadece sınıfsal gruplarına göre siyasi davranış göstermemesi, sınıfların veya sınıf çatışmalarının olmadığını göstermez.

Yukarıda da değinildiği gibi, oy verme davranışları çalışmalarında sınıfların tipik olarak üst- orta- alt gelir grupları olarak ayrılması alışılmadık bir durum değildir. Diğer yandan seçmen davranışı- sınıf ilişkisi literatürü ilk olarak Lipset (1959) tarafından öne sürülen ve daha çok seçmenin eğitim 
seviyesi ile tanımlanan "işçi sınıfı otoriterliği" (working-class authoritarianism) kavramı üzerine biçimlendirilmiştir. 1960’larda yapılan bu çalışmalara göre işçi sınıfı, orta sınıfa mensup olanlara göre daha çok sol görüşe sahip partilere oy vermektedir. İskandinavya ve Britanya'da en yüksek sinıf-temelli oy verme eğilimine sahipken, bu eğilim $A B D$ ve Kanada'da en düşük seviyededir. Lipset ve Rokkan'a göre (1967) toplumsal bölünmeler dörtlü bir modele dayanır: 1.merkez-çevre bölünmesi; 2. devlet-din bölünmesi; 3. kentkır bölünmesi; 4. sınıfsal bölünmeler. Her ne kadar Lipset ve Rokkan, Batı toplumlarında partilerin ortaya çıkışlarını ve toplumsal kökenlerini tarihsel olarak kurumlar ve sınıflar arasındaki çatışmalar ve derin ayrımlar üzerinden yorumlasalar da, sosyal sinıf temelinde oy vermeyi anlamada herhangi bir standart oylama ölçütü sunmamışlardır. Yukarıda değinildiği gibi 1990'lara gelindiğinde sol-sağ ideolojik ayrımına dayanan sınıf temelli oy vermenin gerilediği ve parti özdeşleşmesinin azaldığı düşünülmüş, cinsiyet, etnisite, ırk gibi kimlik temelli post-materyalist değerlerin ve ayrımların sınıf-temelli çatışmaların yerini aldığı ve “yeni sol”"u oluşturduğu varsayılmıştır.

Türkiye'de ise partilerin ortaya çıkışlarını ve toplumsal kökenlerini incelerken genelde Şerif Mardin'in merkez-çevre teorisi temel alınmaktadır. Mardin'in bu teorisi de temelde sosyal sınıf ayrımları üzerine şekillenmiştir. Mardin toplumsal sınıflar ve sınıf bilincine ilişkin açıklama yaparken beş temel kategori üzerinde durmaktadır: Statü farkındalığı (status awareness), tabaka (stratum) farkındalığı, tabaka bağlılığı (affiliation), tabaka bilinci ve tabaka eylemi. Bunları açıklamak gerekirse statü farkındalığı, sürekli olarak statü dizilerinin algılanması yani kendini ve başkalarını konumlandırma yeteneği olarak tanımlanmaktadır. Tabaka farkındalığı ise, kendini ve başkalarını tabakalara yerleştirme geleneği olarak ifade edilmektedir. Bunlar içerisinde sınıf farkındalığı ise ekonomik ölçütlere dayalıdır. Tabaka bağlılığı, bir tabakaya ait olma duygusudur. Bu ırksal, mesleki, dinsel ve sınıf bağlılığı olarak değişebilmektedir. Sınıf bağlılığı ise, salt ekonomik ölçütlere dayalı olarak bir tabaka bağlılığı türüdür. Bu ölçütler bazen ırksal, bazen de yaşama üslubu olarak değişebilmekte ve sınıf bağlılığı bu ölçülere dayanabilmektedir. Bu ölçüler beraberinde bir toplumsal zümreyi (social set) oluşturmaktadır. Son olarak tabaka eylemi ve sınıf eylemi kavramlarına bakılacak olursa; tabaka eylemi, tabakanın çıkarları ve ideolojisi adına davranma olarak tanımlanırken, sınıf eylemi, tabaka eyleminin salt ekonomik ölçütlere dayalı bir türü olarak ifade edilmektedir (Mardin, 1990: 80-81). Mardin'in oluşturduğu terminolojiye göre kapalı konut sitelerinde oturanların yaşama üslubuna dayanan belli bir toplumsal zümreye ait özellikler sergilediğini söyleyebiliriz. 
Batı toplumlarında sınıfların mücadeleler sonucunda siyasi, sosyal ve ekonomik haklar elde ettiği bilinmektedir. Türkiye'de sınıfların ve partilerin ortaya çıkışı benzer şekilde olmamıştır. Özellikle 1923 ile başlayan ve temelleri atılan yeni cumhuriyet ile birlikte bu farklılık daha açık bir şekilde görülmektedir. Cumhuriyet döneminde yapılan reformları değerlendiren Keyder, bu dönemde yapılan kurumsal reformların hiçbir zaman toplumsal muhalefetin bir kazanımı sonucu olmadığını ifade etmiştir. Örneğin, halifeliğin kaldırılması için toplumdan bir talep olmamış veya kadın hakları geniş bir kadın hareketi sonucunda kazanılmamış veya kadın hareketleri resmi tarihte yer almamıştır. Aynı zamanda işçi sınıfının örgütlenme grev hakkı verilmesinde de bir işçi hareketi görülmemiştir. Bu gibi hareketlerin oluşmasına imkân vermeden tependen yapılan reformlar toplumun dinamiklerini etkilemiş ve mücadele, katılım gibi önemli geleneklerin yerleşmesinin önüne geçmiştir (Keyder, 2014: 240). Dolayısıyla Batı toplumlarındaki mücadeleler ile Türkiye'de yapılan sınıfsal mücadele arasında büyük farklılıklar bulunmaktadır. Batı'daki endüstriyel toplumlardaki gibi özerk bir burjuva yerine devlet eliyle devlete bağlı sermaye sahiplerinin oluşturduğu bir sınıf yapısının ortaya çıktığı görülmektedir. Bu süreç sadece cumhuriyet dönemiyle sınırlı kalmamıştır. İktidarı elde eden her grup ya da siyasal düşünce, kendine bağlı kendi elitlerini yaratmıştır. 1980'ler itibariyle başlayan kentleşme hareketleri, liberal ekonomiye geçiş politikası ve özel sektörün canlanması bu durumun bir nebze de olsa azalmasını sağlamıştır. Ancak Türkiye'de yine Batı'daki gibi bir sınıfsal yapının olmadığını belirtmek gerekir. Bunun en temel nedenleri tarihsel olarak üretim şeklinin farklı olması, burjuva sınıfının organik olarak devlete bağlı olması ve işçi sınıfının da muhafazakâr yapısıdır. Dolayısıyla Türkiye'deki tarihsel olarak en belirgin sınıf çatışması burjuvazi sınıfı ve bürokrasi arasındadır. Her ne kadar istikrar isteyen orta-sınıf güçlü hükümetleri desteklese de, aşırı merkezileşmeyi kendi ekonomi alanına müdahale olarak görmektedir. Tablo 1'de yer alan Mart 2019 yerel seçimlerinde büyükşehir belediyelerindeki oy kaymasını sadece iktidar partisinin ekonomik kriterler üzerinden cezalandırması değil, bir sınıfsal tepki olarak da okumak mümkündür.

Yukarıda değinilen sınıf gruplarının siyasi davranışlardaki etkisi üzerine yapılan kapsamlı çalışmalara rağmen, çoğu araştırmacılar sosyal sınıfları ve zümreleri oy verme modellerine dâhil etmiyorlar. Kısmen bu durum sınıfın siyasi tercihlerle ilgili olmadığı yaygın görüşü yansıtmaktadır. Ekonomik oy verme bu soruları daha çok ideolojik eğilimler üzerinden ele alırken, Türkiye'de seçmenin bulunduğu sosyal sınıfın etkilerine değinmez. Ancak çalışmamızda tartıştığımız üzere bu eksik bir yorumdur. 
2000'li yılların başından itibaren hızla artmaya başlayan kent nüfuslarının getirdiği kentsel dönüşüm hareketleri özellikle büyükşehirlerde ekonomik farklılıkları çok daha belirgin hale getirmiştir. Kırdan kente başlayan bu göç hareketleri ile yeni yaşam alanları oluşmaya başlamıştır. Kırsal alandan gelen topluluklar büyükşehirlerde yeni kırsal alanları oluştururken, kentli ve ekonomik düzeyi yüksek olan topluluklar ise bu gruplardan ayrışmaya çalışmıştır. Elbette tek neden bu değildir; ancak kent nüfuslarının artmasıyla birlikte gelen güvenlik sorunu, konforlu yaşam isteği gibi birçok neden ile birlikte kentler içerisinde yeni yaşam alanları oluşturulmuştur. Kapalı konut siteleri olarak adlandırılan bu siteler adeta kent içinde kendilerini kırsaldan ayırarak yeni kentlerini oluşturmuşlardır. Dolayısıyla ekonomik gücün getirdiği bu ayrım kentlerde daha görünür hale gelmiştir. Giddens'ın ifadesindeki gibi sınıflar sadece ekonomik olarak değil birçok açıdan benzerlik gösteren ve bir arada olmak isteyen topluluklardır. Mardin, bu grupları toplumsal zümre olarak tanımlar. Bu noktalardan hareketle bu çalışma, kapalı konut sitelerini benzer yaşam standartlara sahip seçmelerin bir arada yaşadığı alanlar olarak görmekte, seçmenlerin benzer oy tercihinde bulunduğunu ve kitlesel oy tercihlerinin seçim sonuçlarını etkilediğini öne sürmektedir.

\section{Türkiye'de Seçmen Davranışı ve Sınıf-Temelli Oy Verme}

Türkiye'deki seçimler, çok partili hayata geçildiği 1950 yılından itibaren demokrasinin bir aracı olarak kabul görmektedir. Bu 70 yıllık süreç zaman zaman askeri müdahaleler ile kesintiye uğrasa da, Türkiye'de seçmen katılımı Avrupa ortalamasının üstündedir ve rejimin meşruiyetini oluşturur (Taşkın, 2015). Dolayısıyla seçmenin oy verme davranışı ve bunun analiz edilmesi oldukça önem arz etmektedir. Türkiye'de siyasal partilerin politika, söylem ya da daha genel ifadeyle ideolojik yönlerine bakıldığında ana hatları ile laik, milliyetçi, İslamcı ve muhafazakâr olarak ayrışmalar çizdiği görülmektedir (Kalaycıoğlu, 2012:173). Bu eğilimler doğrultusunda 1950'lerden itibaren kurulan partiler iktidara talip olmuşlardır. Ancak süreç içerisinde seçmenin oy verme davranışlarında seçimden seçime değişiklikler olmuş, bir dönem laik söylemelere sahip parti iktidar olurken, başka bir dönemde İslamcı, muhafazakâr partiler iktidarı elde etmiştir.

1950’lerde Türkiye siyaseti Demokrat Parti (DP) ve Cumhuriyet Halk Partisi (CHP) arasındaki rekabete dayalı iki-partili sisteme dayanmaktadır. Bu süreçte iki partinin oy toplamı oyların \%80'inden fazlasını oluşturmaktadır. Ancak işleyiş alanında iki-partili sistemden uzaklaşır; çünkü her ne kadar bu iki partinin arasındaki oy farkı birbirine yakın olsa da blok-oy seçim 
sisteminin yarattığı adil olmayan sandalye dağılımından dolayı DP, meclisteki sandalyelerin büyük bir çoğunluğunu almıştır. Her iki partinin milletvekilleri ve seçmenleri profil olarak birbirine benzerken, DP daha çok CHP'den memnun olmayanları mobilize etmekte başarılı olmuştur. Yine de bu iki parti arasındaki rekabet ve sonrasında kurucu parti CHP'nin karşısındaki en güçlü parti ile ilişkisi, literatürde daha çok merkez-çevre arasındaki mücadele olarak sunulmuştur (Ergüder ve Hofferhert, 1988, 91-93). 1960'larda DP geleneğini sürdüren merkez-sağ Adalet Partisi (AP) oyların \%50'sinden fazlasını almayı başarırken, 1970'lerde CHP merkez-sol partisi olarak oylarını \%40’lara kadar arttırmıştır. CHP ve karşısındaki merkez-sağ partiler 1990lara kadar modern ve merkez partileri olarak sol-sağ çizgisinde yer almışlardır. Sistem-dışı etnik İslami gelenek partileri ise en çok kırsal bölge oylarını ve onların da az bir bölümünü alabilmiştir. Endüstriyel ticaret merkezi olan İstanbul, İzmir, Adana ve Ankara gibi iller daha çok sol partileri desteklerken, 1970lerde bu partiler yine Alevi- Sünni çatışması yaşayan bölgelerden de oy almıştır. Genel olarak merkez-partilerin arasındaki rekabet ve dolayısıyla seçimler merkez-çevre ve sol-sağ etkenleri üzerinde yoğunlaşmıştır. Bu yüzden Türkiye'deki parti rekabetini ve seçmen davranışlarını hem sol-sağ ideolojik görüş farkları, hem bölgesel farklar, hem sınıfsal, hem de merkez-çevre boyutları üzerinden anlamak önemlidir (Tachau, 2002:33).

Türkiye'de seçmen davranışlarını etkileyen faktörler arasında ideoloji, dindarlık, etnisite, cinsiyet gibi sosyolojik özellikler, iktidarların ekonomik performansları ve güncel konular sayılabilir. Bu çerçevede sınıf-temelli oy verme eğilimi ele alınmadan önce Türkiye'deki seçmen davranışlarını açıklamada öne çıkan üç model incelenecektir: ekonomik oy verme, merkezçevre ilişkisi ve mekansal-bölgesel (spatial) oy verme modelleri.

\section{Ekonomik Oy Verme}

Whitten ve Palmer’a göre “ekonomik oylama modeli siyasi partilerin makro-ekonominin iyi performans gösterdiğinde sandıklarda daha iyi sonuç vereceği yönünde basit bir önerme ile başlamaktadır" (1999:51). Bu açıdan ekonomi, modern demokrasilerde politika oluşturmada çok önemli bir role ve alana sahiptir Ekonomi politikasının etkisiyle oluşturulan girdi ve çıktılar seçmenin değerlendirme yapmasını sağlamaktadır. Bu bağlamda seçmen davranışı ile geriye dönük ekonomik değerlendirmeler arasında bir ilişkinin olduğu görülmektedir. Ekonomik kararlardan sorumlu olan partinin açık olarak belirlenmesi durumunda seçmen bu partiyi ödüllendirebilmekte veya cezalandırabilmektedir (Debus, Stegmaier ve Tosun, 2014:50-51). Ekonomik performansın hükümetin popülerliğinde veya bu popülerliğinin azalmasında 
kısa süreli değişikliklere neden olduğu yönünde ortak kanı bulunmaktadır (Power, 2015:391).

Seçmen davranışı ve ekonomik performans arasındaki ilişkiyi inceleyen bir takım hipotezler içerisinde en önemlisi "sorumluluk" hipotezidir. Bu hipoteze göre eğer işsizlik ve enflasyon oranları yüksek düzeylerde seyrediyorsa sorumlu hükümete ceza kesilmekte, düşük düzeyde ise de iktidar ödüllendirilmektedir. (Çinko, 2006:106). Diğer bir hipotez "müvekkil” hipotezidir. Buna göre, ister iktidarda ister muhalefette olsun, yüksek işsizlik oranları sol partilerin popülaritesini arttırmakta, yüksek enflasyon oranları ise tam ters olarak sağ partilerin popülaritesini arttırmaktadır. Bu yaklaşımlarda göz ardı edilen nokta seçmenlerin bulundukları sosyal sınıfa göre de ekonomik performansı değerlendirdiğidir. Ekonomik oy verme davranışında sadece ekonomik performansın önemli olmadığını vurgulamaktadır (Sipahi, 2014). Seçmen aynı zamanda bir şekilde rasyonel olan nedenlerle ideolojik tercihlerini de yapmakta ve bu tercihler seçimlerde kolay kolay değişmemektedir. Yani bir partiyi iktidardan indirecek tek şey ekonomi değildir. İktidarda olmanın dezavantajı da göz önünde bulundurulmalıdır. Bu faktörler ile birlikte ekonomik oy tercihi birleşince temelde çok büyük oy değişimleri görülmemektedir.

Ekonomik oy modeli Türkiye özelinde değerlendirildiğinde, en belirgin örnek olarak 2001 iktisadi kriz sonucunda koalisyon hükümeti ortakları Demokratik Sol Parti (DSP), Anavatan Partisi (ANAP) ve Milliyetçi Hareket Partisi'nin 2002 seçimlerinde parlamento dışında kalması ve yeni kurulan AK Parti'nin tek başına iktidara gelmesi sunulur. Çarkoğlu (2012) ise seçmen oylarındaki bu keskin değişimin sadece ekonomik değil, ideolojik oy verme davranış modeli temelinde incelenmesi gerektiğine dikkat çeker. AK Parti’nin 17 yıllık iktidarına bakıldığında ise, 2008 yılında yaşanan küresel kriz, 1725 Aralık operasyonu, son dönemlerde yaşanan döviz hareketlilikleri, yüksek enflasyon ve yüksek işsizlik oranlarına rağmen özellikle genel seçimlerde büyük oy kayıpları yaşanmadığı görülmektedir. Diğer yandan son yerel seçimler incelendiğinde yaşanan ekonomik problemlerin de etkisiyle iktidarın büyükşehirlerde büyük kayıplar yaşadığı görülmektedir.

Tablo 1. 2014-2019 Yerel Seçim Sonuçları

\begin{tabular}{llll}
\hline Şehir & 2014 & 2019 & Nüfus \\
\hline İstanbul & AKP & CHP & 15.067 .724 \\
Ankara & AKP & CHP & 5.503 .985 \\
İzmir & CHP & CHP & 4.320 .519 \\
Bursa & AKP & AKP & 2.994 .521
\end{tabular}




\begin{tabular}{llll} 
Antalya & AKP & CHP & 2.426 .356 \\
Adana & MHP & CHP & 2.220 .125 \\
Konya & AKP & AKP & 2.205 .609 \\
Şanlıurfa & AKP & AKP & 2.035 .809 \\
Gaziantep & AKP & AKP & 2.028 .563 \\
Kocaeli & AKP & AKP & 1.906 .391 \\
Mersin & MHP & CHP & 1.814 .468 \\
Diyarbakır & BAČIMSIZ & HDP & 1.732 .396 \\
Hatay & CHP & CHP & 1.609 .856 \\
Manisa & MHP & MHP & 1.429 .643 \\
Kayseri & AKP & AKP & 1.389 .680 \\
\hline
\end{tabular}

2014 yerel seçimleri ile 2019 yerel seçim sonuçlarını karşılaştıran Tablo 1 incelendiğinde, birçok büyükşehrin -İstanbul ve Ankara dahil- 25 yll sonra ana muhalefet partisi CHP'nin yönetimine geçtiği, CHP'nin toplamda daha büyük bir nüfusu yönettiği ortaya çıkmaktadır. Her ne kadar ekonomik olarak gelişmiş büyükşehirlerin önceki seçimlere göre parti tercihini değiştirdiği görülse de büyük şok etkisi yaratan 2019 yerel seçimlerini sadece iktidarın cezalandırılmasına dayanan ekonomik oy verme modeli üzerinden okumak sinırlı bir analiz sunacaktır. Bu tercihler 2017'de Başkanlık sistemine geçişin oylandığı anayasa referandumu ile paralellik göstermekte, CHP’nin kazandığı birçok ilde referandum sonucunda HAYIR oyları daha fazla çıkmıştır. Bu sonuç, Türkiye'deki tarihsel sınıf ilişkileri üzerinden incelendiğinde orta-sınıfın gittikçe gücünü arttıran ve merkezileşmeyi hedefleyen bürokrasiye karşı tepkisi olarak da yorumlanabilir. Sınıfsal analiz öncesi Türk siyasetini ve seçmen davranışlarını incelerken en çok yararlanılan merkez-çevre ilişkisini tanımlamak gerekmektedir. Diğer bir değişle, seçim sonuçları, çevrenin merkeze yerleşmesine karşı sınıfsal bir uyarı niteliğindedir.

\section{Merkez-Çevre}

Şerif Mardin tarafından literatüre kazandırılan merkez-çevre kavramı başta siyaset bilimi olmak üzere sosyal bilimlerin birçok alanında kullanılmaktadır. Osmanlı'da "merkez" yönetici seçkinlerini "çevre” ise, seçkin olmayan tebaa'dan oluşmaktadır. Cumhuriyet döneminde de merkez ve çevre ilişkileri benzer şekilde devamlılık göstermiştir (Heper,1985). Toplumsal anlamda devam eden bu süreklilik, çok partili hayata geçilmesiyle birlikte seçimlerde de görülmektedir (Çarkoğlu, 2012:162). Merkezin ve çevrenin açık bir temsilcileri olmamasına rağmen dönemin partileri olan CHP, elitlerin, devlet kurucuların ve dolayısıyla merkez'de yer alan parti konumundadır. CHP'nin 
içinden çıkarak yeni bir oluşum gerçekleştiren DP ise, daha çok köylünün, tebaanın yani çevre'nin partisi görünümünde olmuştur. Seçmen davranışını ve parti sistemlerini de etkileyen bu duruma dayanarak merkezci partilerin temelde daha düşük dindarlık seviyesine sahip, etnik veya mezhepsel azınlık gruplarına ait olmayan (veya ait hissetmeyen) kentsel seçmenler tarafından tercih edilmelerini beklemektedir. Çevre partilerinin ise, daha dindar, görece kırsalda yaşayan ve eğitim seviyesi daha düşük seçmenlere hitap etmesi ve onlar tarafından tercih edilmesi beklenmektedir (Çarkoğlu:2012:163). Seçim sonuçları ve yapılan araştırmalar merkez-çevre ilişkisinin Türk toplumunda ve seçmen davranışında önemli bir faktör olduğu görülmektedir. Bu ayrışmanın getirdiği farklılaşma aslında temelinde sınıfsal ayrımları barındırırken, bölgeler arası farklılaşmayı da beraberinde getirmektedir.

Yine de seçmenlerin sosyo-ekonomik ve kültürel değerleri ile parti tercihleri arasındaki ilişki statik değildir. Ergüder'in çalışmasına göre (2000, 295-301) 1965-1977 arasındaki dönemde parti destekleme tabanındaki değişiklikler göze çarpmaktadır. CHP ve AP merkez-sol ve sağ parti olarak konumlanırken, CHP kendini merkez olarak tanımlayan seçmen tarafından daha çok tercih edilmekte, ortanın sağındakilerden de az da olsa destek almaktadır. 1960'larda AP kırsal bölgelerin yanısıra endüstriyel büyükşehirlerden de oy alırken, 1977'ye gelindiğinde modernleşme düzeyi yüksek illerde CHP’ye karşı oy kaybetmeye başlamış, CHP ise kırsal bütünleşme boyutu itibariyle gelişmiş illerde ve kentlerde daha güçlü bir parti haline gelmiştir. Sanayileşmiş ve ticarileşmiş illerde küçük etnik, milliyetçi ve İslamcı partiler (MHP ve MSP gibi) oldukça zayıftır. Seçmen bakımından merkeziyetçi eğilim 1990’lara kadar Türk politik hayatında egemendir. Meslek olarak kentlerdeki işçi ve memurlar CHP'yi desteklemektedir. Bu çalışmadaki en ilginç nokta, 1970’lerde CHP'nin genç gruplara hitap ettiğinin belirtilmesidir. Son yapılan çalışmalar ise, seçmenin yaşı arttıkça CHP’yi tercih etme olasılığının arttığını göstermektedir. Genç seçmen daha çok aşırı sağ ve sol partilere yönelmektedir. Ergüder'in çalışmasındaki sınıf temelli oy vermeyi gösteren en önemli bulgu Türkiye'de eğitim görmüş vatandaş sayısının artmasıyla AP'nin aleyhine bir eğilim oluştuğu görülmesidir. İlkokula devam edip de mezun olamamışlar arasında AP ve CHP 'nin gücü hemen hemen eşittir. Fakat eğitim düzeyi arttıkça, seçmenler kendilerini artan oranda CHP ile özdeşleştirmektedirler. Ergüder'in çalışması ile süreklilik gösteren diğer bir parametre şehirlere göç eden yoksul kesimde artan sınıf bilincidir. Merkez-çevre çatışması temelinde görülse de bu sınıfsal bilinç sağ partilerin oylarını konsolide etmesini sağlamıştır.

Yine seküler- İslamcı toplumsal ayrışmasında, dindarlık arttıkça sağ partilere oy verme oranının arttığı görülmektedir. 1950'lerden günümüze bu 
partiler, DP; AP; MSP; ANAP; RP; FP ve AK Parti olarak karşılık bulur; ancak ANAP -DYP seçmeni ile RP- FP arasında önemli bir fark bulunmaktadır. 2000lerin başındaki partilerin sınıflara göre oy tabanlarına bakıldığında, seküler sağ partiler üst ve üst-orta sınıftan daha çok oy alırken; İslamcı sağ partiler alt sınıf tarafından daha çok desteklenmektedir. CHP- DSP gibi sosyal demokrat seküler partilerin oy destekleri üst-orta ve orta sinıftan gelmektedir. İlginç olarak aşırı-sağ ama milliyetçi-seküler parti MHP en çok oyunu üst sınıf ve üst-orta sınıftan almaktadır. Bu çalışmada vaka olarak incelenen kapalı konut Tuzla Evora sitesinde 2018 milletvekili seçimlerinde en yüksek oyu İyi Parti'nin alması, MHP’nin tabanı düşünüldüğünde şaşırtıcı değildir. Daha önce MHP’yi tercih eden milliyetçi üst-orta ve üst gelir grupları tercihini ağırlıklı olarak İYİ Parti'den yana kullanmıştır.

\section{Mekansal veya Bölgesel (Spatial) Oy Verme}

Türkiye'de parti sisteminin ayırt edici bir özelliği de oy değişkenliğinin (volatility) çok yüksek olmasıdır. Oy değişkenliğinin yanı sıra 1950'lerden itibaren parti sisteminin parçalanmasının giderek arttığı görülmektedir. Başka bir deyişle, Türk seçmenler sadece partileri sık sık değiştirmekle kalmamış, aynı zamanda oylarını daha fazla partiye bölme eğiliminde olmuşlardır (Çarkoğlu, Avc1, 2002:115). Bu doğrultuda bir analiz yapan Çarkoğlu ve Avcı Türk partilerini üç grup şeklinde sınıflandırmıştır: Merkez-sol, merkez sağ ve İslamcı/Milliyetçi. Bu gruplar ile partilerin 1950-1999 arası seçimlerde illere göre bir korelasyon analizini yapan araştırmacılar, örneğin İslamcı/Milliyetçi partilerin coğrafi olarak Kastamonu, Kırşehir, Sinop, Çankırı, Erzurum, Uşak gibi Anadolu illerinden destek aldığını ortaya koymuşlardır (Çarkoğlu, Avcı, 2002:119). 2002 ve sonrası seçimlere bakıldığında özellikle kıyı şehirlerinin (Akdeniz ve Ege) sol'a daha yakın olduğu ve bu bölgelerin seçmenlerinin tercihlerinin kolay kolay değişmediği görülmektedir. Aynı şekilde İç Anadolu seçmeni ise daha çok muhafazakâr ve milliyetçi kanatta yer almaktadır. Bu iki duruma örnek olarak İzmir ve Konya şehirleri verilebilir. Doğu ve Güneydoğu Anadolu bölgelerinde ise 1990'lardan sonra Çarkoğlu'nun belirlediği parti gruplarına ek olarak dördüncü kategori olan Kürt milliyetçisi seçmenin tercihinin hâkim olduğu görülmektedir. Bu bölgelerdeki şehirlerin uzun yıllardır ilk tercihi HDP ve buna eş diğer Kürt hareketi partileri olmuştur. AK Parti iktidarından sonra bu bölgede etkili olsa da genellikle HDP ilk sırada olmuştur. Büyükşehirlere bakıldığında ise, kentleşmenin sonucunda seçmenin daha heterojen yapıya sahip olduğu görülmektedir. Özellikle Anadolu şehirlerinden gelen göç dalgasının da etkisiyle birlikte kırsalın oy tercihlerinin 1994 seçimlerinden itibaren İstanbul'da etkili olduğu görülmektedir. 
Uzun yıllar bölgesel seçmen ve parti tercihleri arasında bu ilişkinin hakim olmasına rağmen Tablo l'de de görüleceği üzere 2019 seçimlerinde büyükşehirlerdeki seçmenlerin oy tercihi sağdan sola kaydığı görülmektedir. Bu durum yukarıda değinilen 1965-1977 yılları arasındaki AP- CHP çekişmesi ile benzerlik göstermektedir. Büyükşehirlerde coğrafi olarak seçmen analizi yapmak zordur. Anadolu şehirlerin de ise ideolojinin ve seçmen tercihinin daha görünür olması dolayısıyla analizlerin yapılması görece daha kolaydır; çünkü bu şehirlerin demografik yapılarında büyük değişiklikler olmamaktadır.

Yukarıda değinilen bu üç oy verme davranışında her ne kadar gelir ve ideoloji gibi etkenler keşişse de, sınıf-temelli oy verme davranışı genellikle göz ardı edilmiştir. Tablo 2'de Dünya Değerler Anketinin 2005-2009 dönemi (2007 senesi);2010-2014 dönemi (2012 senesi) ve 2017-2020 dönemi (2018 senesi) için yaptığı üç anket sonucu, Türkiye'deki sosyal sınıf ve parti tercihleri üzerinden karşılaştırılmıştır. 2007'de yapılan anket sonuçlarına göre, 'yarın seçim olsa hangi partiye oy verirsiniz' sorusuna katılımcıların \%33'ü AK Parti, \%12'si CHP, \% 6,6’sı MHP, \%5’i DTP’ye oy vereceğini söylemiştir. 2012'de yapılan anket sonuçlarına göre, katılımcıların \%44'ü AK Parti, \%22'si CHP, \%8'i MHP'ye, \%4'ü BDP'ye oy vereceğini belirtmiştir. Bu tabloya göre AK Parti devamı olduğu İslamcı çizgideki RP ve FP'den farklı olarak, merkez-sağdaki ANAP ve DYP'nin de oylarını kazanarak sadece alt ve alt-orta s1nıfın değil, üst ve üst-orta sınıfın da oylarını almayı başarmıştır. Ancak Tablo 3'te verilen 2015 seçim sonuçlarına göre bu oylar MHP'ye; Tablo 2'ye göre de 2018'de İYİ Parti'ye yönelmiştir.

Tablo 2. Parti Desteği Sınıfsal Taban İlişkisi (2007/ 2012/ 2018 Anketi)

\begin{tabular}{|c|c|c|c|c|c|c|}
\hline $\begin{array}{l}\text { Sosyal } \\
\text { Siniflar } \\
\text { (sübjektif) }\end{array}$ & CHP & MHP & AKP & İYÍ P. & DTP-BDP & Diğer \\
\hline Üst sinıf & $\begin{array}{l}10,8 / \mathbf{2 6 , 3 /} \\
48\end{array}$ & $7,3 / 9 / 4$ & $40,4 / 39,2 / 32$ & $-/ / / 8$ & $0 / 11,3 / 0$ & $0 / \mathbf{3 , 7} / 0,7$ \\
\hline Üst-orta sinif & $\begin{array}{l}14,9 / \mathbf{2 6 , 7 /} \\
24,4\end{array}$ & $5,3 / \mathbf{1 0 , 5} / 12$ & $\begin{array}{l}35,2 / \mathbf{3 9 , 4} / \\
42,4\end{array}$ & $-/-/ 6,6$ & $\begin{array}{l}2,1 / \mathbf{2 , 5 /} \\
4,8\end{array}$ & $1,1 / 1, \mathbf{5} / 0$ \\
\hline Alt-orta sinif & $\begin{array}{l}12 / \mathbf{2 1}, \mathbf{3} / \\
26,8\end{array}$ & $6,6 / 7,3 / 11,5$ & $32,3 / \mathbf{4 6 , 5} / 42$ & $-/ / / 3,6$ & $\begin{array}{l}5,7 / \mathbf{4}, \mathbf{1} \\
8,1\end{array}$ & $\begin{array}{l}0,8 / \mathbf{1}, \mathbf{7} / \\
0,9\end{array}$ \\
\hline İş̧̧i sınıfı & $\begin{array}{l}12,5 / \mathbf{2 1} / \\
16,1\end{array}$ & $8,3 / \mathbf{5 , 5} / 9$ & $30,3 / \mathbf{4 3} / 53$ & $-/-/ 4,4$ & $\begin{array}{l}7,3 / \mathbf{5}, \mathbf{3} / \\
10,9\end{array}$ & $\begin{array}{l}1,4 / \mathbf{1}, \mathbf{l} \\
0,3\end{array}$ \\
\hline Alt simif & $\begin{array}{l}7,7 / \mathbf{1 6}, \mathbf{3} / \\
9,2\end{array}$ & $4,3 / 11,8 / 13,2$ & $36,4 / \mathbf{5 0 , 2} / 54$ & $-/-/ 4$ & $\begin{array}{l}1,7 / 1,7 / \\
14,9\end{array}$ & $3,5 / \mathbf{2 , 2} / 0$ \\
\hline Toplam & $\begin{array}{l}12 / \mathbf{2 2}, \mathbf{1} / \\
21,5\end{array}$ & $6,6 / 7,7 / 10,8$ & $33 / \mathbf{4 3}, 7 / 46$ & $-/-/ 4,7$ & $\begin{array}{l}4,9 / \mathbf{4 , 1} / \\
8,6\end{array}$ & $\begin{array}{l}1,2 / \mathbf{1 , 5} / \\
0,7\end{array}$ \\
\hline
\end{tabular}

Kaynak: 2005-2009; 2010-2014; 2017-2020 WVS (Dünya Değerler Anketi)

Soru: Yarın seçim olsa hangi partiye oy verirsiniz? 
Tablo 2'de verilen anket sonuçlarına göre 2007'deki tercihlere göre 2012'de CHP tüm sınıflar genelinde oylarını arttırmıştır; ancak üst ve üst-orta sınıf oylarını önemli ölçüde mobilize etmeye başladığı görülmüştür. 2018 anket sonuçlarına göre özellikle üst sınıf grubunda oy oranını iki katına çıkarmıştır. Diğer yandan sol partilere oy vermesi beklenen iş̧̧i sınıfı ve alt sınıf seçmeninde 2018 anketinde CHP'nin oy kaybettiği farkedilmektedir. İlginç olarak 2007'de en fazla oy potansiyeli işçi sınıfı olan MHP ve BDP, benzer şekilde 2012'ye gelindiğinde üst ve üst-orta sınıftan daha fazla oy almaya başlamıştır. Üst-sınıftan oy alabilme başarısı özellikle DTP-BDP Kürt hareketi için dikkat çekicidir. Bu yönelim 2018 anketinde tersine değişmiş, HDP ve MHP’nin en yüksek oy oranını alt-sınıftan alabildiği görülmüştür. Diğer yandan, İYİ Parti üst-sınıfın oylarının \%8'ini alma potansiyeli göstermiş, MHP'nin ve AK Parti'nin bu gruptaki düşen oylarını toplamıştır. 2012'deki ankete göre bu diğer üç partinin tersi yönde, AK Parti'nin üst ve üst-orta sınıf tarafından tercih edilme oranı azalmış, en fazla desteği \%50,2 ile alt sınıftan aldığı görülmüştür. Bu değişimde 2010 Halk oylamasının yarattığı toplumsal kutuplaşmanın ve seküler- İslamcı çatışmasının artmasının etkileri olduğu düşünülebilir (bkz Tablo 4). 2018'de AK Parti'nin en çok yine işçi sınıfı ve alt-sınıf grupları tarafından tercih edildiği görülmekte, diğer yandan üst-sınıf seçmeni arasındaki oy düşüşü göze çarpmaktadır.

Şehirlerin demografik yapılarının kentleşmenin ve göçün etkisiyle birlikte değiştiği görülmektedir. Bu değişim sadece rakamsal değil aynı zamanda sosyolojik ve siyasal değişimleri de beraberinde getirmektedir. Kırdan kente yoğun olarak göçün 1980'lerden itibaren başlamasıyla birlikte demografik yapının getirdiği değişiklik seçmen davranışını beraberinde de seçim sonuçlarını değiştirmiştir. Özellikle İstanbul'da 1994 itibariyle muhafazakâr/İslamcı partinin büyükşehir belediyesini almasıyla başlayan süreçte kent içerisinde yeni kırsal bölgeler oluşmuştur. Anadolu yakasında Sultanbeyli ve Sancaktepe gibi ilçeler bu alanlara örnek olarak verilebilir. Bu bölgeler seçmenin bölgesel olarak oy verme tercihinde bulunduğu yerler olarak dikkat çekmektedir. Yaşanılan bölgenin oy verme tercihine etkisi olduğu Ataşehir, Maltepe, Beşiktaş, Sultanbeyli ve Sancaktepe gibi konsolide olmuş semtlerin seçim sonuçlarında rahatlıkla gözlenebilmektedir.

Kırsaldan gelen göçün etkisiyle yeni yerleşim yerleri artarken kentte yaşayan ve ekonomik düzeyi yüksek olan topluluklarda heterojen yaşamak yerine kendilerine benzeyen gruplar ile birlikte oluşturulan yeni bölgelerdeki kapalı konut sitelerinde beraber yaşamayı birçok nedenden ötürü tercih etmektedirler. Bulundukları mahallelerden bile soyut şekilde olan bu yaşam alanları, hem sosyolojik olarak hem de siyasal olarak bir sinıflandırmayı getirmektedir. 
Bu da bölgelerin seçim sonuçlarına etki etmektedir. Özetle, kent kırsal bölgesel ayrımı kentlerin kendi içerisinde devam ettiğini söylemek mümkündür. Sadece kent ile kırsal arasındaki mesafe artık bir duvar kadar azalmıştır.

\section{Kapalı Konut Siteleri ve Seçim Sonuçlarına Etkileri: Tuzla/Evora Konutları Örneği}

Kapalı-konutlarda yaşamak bir tercih olsa da, bu tercih belirli gelir seviyesine sahip gruplar için mümkün gözükmektedir. Kentleşme olgusunun hızla arttığı metropol olarak ifade edilen şehirlerde kapalı sitelerin aynı hızda arttığı görülmektedir; ancak kapalı-konutların ortaya çıkması sadece güvenlikle ilgili sonuçlar doğurmamıştır. Bu kapalı sitelerin kuruldukları bölgelerde mahalle kültürü ve mahalle sakinleri arasında sosyal ayrışmayı ortaya çıkardığı gibi, seçimler üzerinde de önemli etkilerinin olduğu göze çarpmaktadır. Seçim sonuçları incelendiğinde oy tercihinin bulundukları mahallelerden farklı olduğu görülmektedir. Dolayısıyla sosyal sınıf olarak ayrışan toplu konut ya da kapalı konut siteleri siyasal anlamda da farklılaştığı görülmektedir. Güvenlik, statü, konfor gibi çeşitli nedenlerle şehir içerisinde şehir olarak adlandırılan bu alanlar aynı zamanda bir arada yaşayan insanların benzer oy tercihlerinde bulunduklarını da göstermektedir. Lüks yerleşim yerlerinde oturan nüfus ise Türkiye'deki seçmen davranışları tarihi ile paralel (ama Batı toplumları ile ters) olarak sol-eğilimli partileri daha çok tercih etmektedir. Diğer bir deyişle, aslında kentsel dönüşüm projeleri iktidar partisine uzun vadede oy kaybettirmektedir. Bu doğrultuda öncelikli olarak kapalı konut sitelerinin literatürdeki yerini incelenecek olup, sonrasında ise, yaklaşık 15 bin nüfusa sahip İstanbul'un Tuzla ilçesindeki Aydıntepe mahallesinde 2011 yılından itibaren yapılmaya başlayan ve 2015 yılında yerleşime açılan Evora evlerinin seçmen davranışlarının analizi yapılacaktır. Bu analiz yapılırken bölgenin YSK verilerinden elde edilen seçim sonuçları kapalı konut öncesi ve sonrası olarak sunularak karşılaştırılacaktır.

\section{Kapalı Konut Siteleri}

Kapalı konut siteleri en genel anlamıyla, kamusal alanın özelleştirilerek sınırlı girişin sağlandığı yerleşim alanları olarak tanımlanmaktadır (Blakely and Snyder, 1997:2). Literatürde bu yerleşimler yaygın olarak "gated communities” olarak kullanılmakta, ancak farklı yazarlar tarafından "edge cities” (kenar kentler) (Garreau, 1991), "gated enclaves” (kapılar ardındaki yerleşim bölgeleri) "enclosed neighbourhoods" (kapalı mahalleler) "fortified enclaves” (duvarlarla çevrelenmiş yerleşim bölgeleri) (Calderia, 1996), “enclosed 
housing developments" (kapalı konut yerleşimleri) (Glasze, 2003) farklı şekillerde yapılan tanımlamalar da mevcuttur.

Kapalı siteler çevresi duvar veya çitlerle örülü olan, yaya, bisiklet ve otomobil girişlerinin sınırlandırıldığı yerleşim alanlarını ifade etmektedir (Yakışan, 2008:19). Kapalı sitelerin mekânsal bir anlamı olsa da, sakinlerinin yaşam tercihlerini yansıttığı da bilinmektedir. Blakely ve Snyder (1997) kapalı konutları, bu yaşam tercihlerinin bir yansıması olarak görmüş ve yaşam tarzı, prestij ve güvenlik amaçlı olmak üzere kapalı konutları üçe ayırmıştır. Buna göre, kapalı konutları tercih edenlerin özellikleri tek yönlü olarak düşünülemez, dolayısıyla bu konutlarda yaşayanların sorunlarında da farklılıklar gözlemlenebilmektedir. Öte yandan, site yönetimlerinin yerel yönetimler bağlamında aktif rol oynamalarına ve yönetimi yeniden yerelleştirmelerine dikkat çeken Blakely ve Snyder (1997), bu yönetimleri sözde yeni yerel yönetimler olarak tanımlamaktadır.

Site yönetimlerinin, yerel yönetimler bağlamında öne çıkmasını vurgulayan bir diğer yazar olan Kennedy (1995), bu birliklerin devlet aktörleri olarak görülmeleri gerektiğini savunmaktadır. Bu çalışmaya göre, site yönetimlerinin birer devlet aktörü olduklarına dair en büyük örnek, sitelerin yollar, parklar, sağlık koruma, polis koruması gibi devlet tarafından sağlanan hizmetleri sağlayarak esasında kamu görevlerini yerine getirirken, özel görevlileri de kamu görevlisi yerine istihdam edebilmeleridir.

İstanbul'da kapalı konut sitelerin sayısı 2290'dır. Sitelerin bulunduğu hatlar; Boğaz ve çevresi, Beylikdüzü-Esenyurt-Başakşehir, Sarıyer-Kilyos, Maltepe-Tuzla, Ataşehir-Çekmeköy ve Beykoz bölgesidir (Candan ve Özbay, 2014: 60). 
Şekil 1. Kapalı Sitelerin Yoğunlaştığı İstanbul İlçeleri

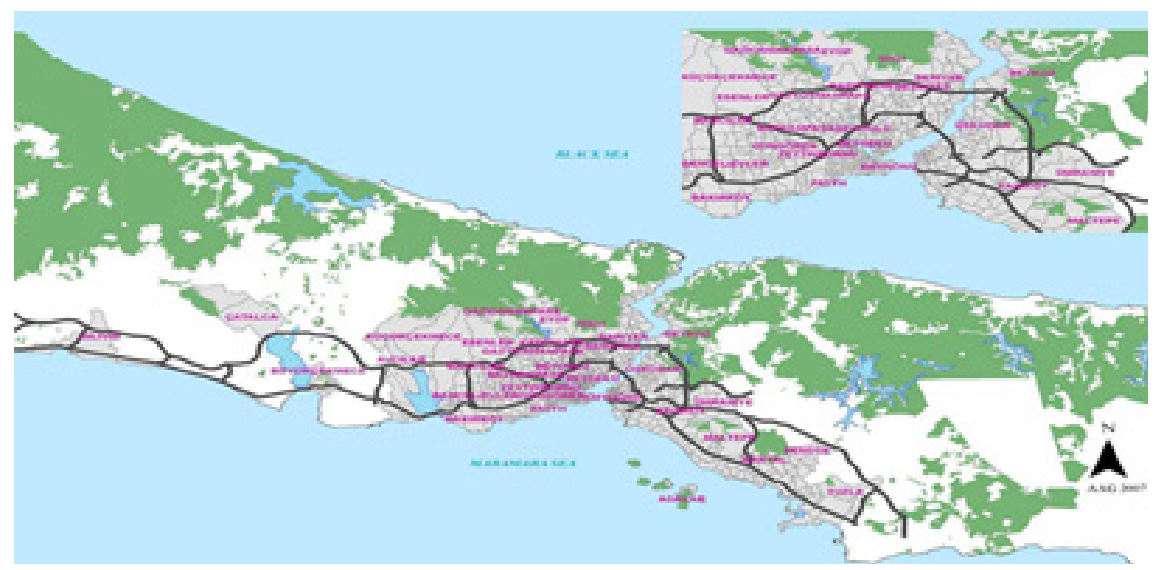

(Baycan, Akgün, 2012:92)

\section{Kapalı Konut Sitesinden Önceki Seçim Sonuçları ve Analizi}

Tuzla Aydıntepe mahallesindeki seçmen sayısı siteler kurulmadan önce 2011 yılındaki milletvekilliği seçiminde 10.641 olarak verilmiştir. 1 Kasım 2015'de yapılan seçimde ise bu sayının 13.797’e çıktığı görülmektedir (YSK, 2019). Diğer bir deyişle, dört yıllık süreç içerisinde mahalledeki seçmen sayısının doğal artışı 3000'den biraz fazla olmuştur. Bu da yıllık yeni seçmen sayısının 750 kişi arttığını göstermektedir. Dört yıllık süreç içerisinde üç tane genel seçim yani milletvekilliği seçimi bir tane de yerel seçim yapılmıştır. Siteden sonraki partinin oy oranlarını ve artışlarını karşılaştırmak için önceki bu dört seçimin sonuçlarını analiz etmek gerekmektedir.

Tablo 3. Site Öncesi Seçim Sonuçları

\begin{tabular}{|c|c|c|c|c|c|c|c|c|}
\hline Seçimler & $\begin{array}{l}\text { Seçmen } \\
\text { Sayısı }\end{array}$ & $\begin{array}{l}\text { Seçime } \\
\text { Katılan } \\
\text { S.S } \\
\end{array}$ & $\begin{array}{l}\text { Katilım } \\
\text { Oranı }\end{array}$ & $\begin{array}{l}\text { AK } \\
\text { Parti }\end{array}$ & CHP & $\overline{\bar{E}} \overline{I P}$ & HDP & SP \\
\hline $\begin{array}{l}\text { 24. Dönem MV } \\
\text { (12.06.2011) }\end{array}$ & 10641 & 9280 & $\% 87.21$ & $\begin{array}{l}6195 \\
(\% 70)\end{array}$ & $\begin{array}{l}1273 \\
(\% 15)\end{array}$ & $\begin{array}{l}972 \\
(\% 11)\end{array}$ & $\begin{array}{l}87 \\
(\% 1)\end{array}$ & $\begin{array}{l}279 \\
(\% 3)\end{array}$ \\
\hline Tuzla B. B. (30 Mart 2014) & 11155 & 10009 & $\% 89.73$ & $\begin{array}{l}6016 \\
(\% 65)\end{array}$ & $\begin{array}{l}2391 \\
(\% 26)\end{array}$ & $\begin{array}{l}454 \\
(\% 5)\end{array}$ & $\begin{array}{l}83 \\
(\% 1)\end{array}$ & $\begin{array}{l}337 \\
(\% 3)\end{array}$ \\
\hline İBB (30 Mart 2014) & 11155 & 10007 & $\% 89.71$ & $\begin{array}{l}6339 \\
(\% 68)\end{array}$ & $\begin{array}{l}2293 \\
(\% 24)\end{array}$ & $\begin{array}{l}377 \\
(\% 4)\end{array}$ & $\begin{array}{l}94 \\
(\% 1)\end{array}$ & $\begin{array}{l}246 \\
(\% 3)\end{array}$ \\
\hline $\begin{array}{l}\text { 25. Dönem(2015) MV. } \\
(07.06 .2015)\end{array}$ & 12356 & 10592 & $\% 85.72$ & $\begin{array}{l}5592 \\
(\% 59)\end{array}$ & $\begin{array}{l}1.642 \\
(\% 17)\end{array}$ & $\begin{array}{l}1.427 \\
(\% 15)\end{array}$ & $\begin{array}{l}347 \\
(\% 4)\end{array}$ & $\begin{array}{l}430 \\
(\% 5)\end{array}$ \\
\hline 1 Kasım 2015 MV & 13797 & 12236 & $\% 88.69$ & $\begin{array}{l}7473 \\
(\% 63)\end{array}$ & $\begin{array}{l}2523 \\
(\% 21)\end{array}$ & $\begin{array}{l}1370 \\
(\% 11)\end{array}$ & $\begin{array}{l}423 \\
(\% 4)\end{array}$ & $\begin{array}{l}158 \\
(\% 1\end{array}$ \\
\hline
\end{tabular}


Tablo 2'e bakıldığında iktidar partisinin mahallede seçime katılım oranının yüksek olduğu görülmektedir. Tüm seçimler incelendiğinde mahallenin seçime katılan seçmeninin oy tercihinin genel ve yerel seçim ayırt etmeksizin \%50'den fazlasının AK Parti lehinde oy kullandığı görülmektedir. Yalnız 2015 seçimlerinde bir düşüş yaşamış olan iktidar partisi koalisyon hükümeti kurulamayıp tekrar erken seçime gidince Türkiye genelinde olduğu gibi Aydıntepe mahallesinde de oylarını arttırmıştır. Bu süreç içerisinde Türkiye'de yaşanan siyasal ve ekonomik gelişmelerin bu mahalle özelinde (ve Türkiye genelinde) seçmen tercihini çok fazla değiştirmediği görülmektedir. Dolayısıyla seçmenin AK Parti üzerinde konsolide olduğunu ve tercihini değiştirmediği söylenebilir.

CHP'nin ise, belirli bir oy oranının olduğu ancak bunun üstüne çlkamadığı görülmektedir. MHP'nin ise yerel seçimlerde çok düşük bir oyunun olduğu genel seçimlerde ise, oylarını yıllar içerisinde arttırdığı görülmektedir. HDP ve SP'nin oylarının olduğu ancak bu oyların çok etkili oranda olmadığı görülmektedir.

Tablo 4. 2010 ve 2017 Halk Oylaması Sonuçları

\begin{tabular}{llllll}
\hline Referandumlar & $\begin{array}{l}\text { Kayıth } \\
\text { Seçmen Sayısı }\end{array}$ & $\begin{array}{l}\text { Seçime } \\
\text { Katılan S.S. }\end{array}$ & Katılım oranı & Evet & Hayır \\
\hline $\mathbf{2 0 1 0}$ & 10745 & 7823 & $\% 73.27$ & $\begin{array}{l}5798 \\
(\% 75)\end{array}$ & $\begin{array}{l}1966 \\
(\% 25)\end{array}$ \\
2017 & 16699 & 14823 & $\% 88.77$ & $\begin{array}{l}8006 \\
(\% 55)\end{array}$ & $\begin{array}{l}6617 \\
(\% 45)\end{array}$ \\
\hline
\end{tabular}

Cumhurbaşkanlığı seçimlerini ve referandum seçimlerini de ayrıca incelemek gerekmektedir. Bu bağlamda siteler öncesi yapılan seçimlerden bir tanesi 2010 yılında anayasa değişiklikleri için yapılan halkoylamasıdır. Bu oylamaların sonuçlarına bakıldığında iktidar partisinin “evet” muhalefetin ise "hayır" üzerinden propagandalar yürüttüğü bilinmektedir. Bu bağlamda mahallede katılımın diğer seçimlere oranla biraz düşük olduğu görülmekte ancak yine bu oranın normal seviyelerde olduğunu söylemek gerekir. 2017 halkoylaması seçimlerini incelemek gerekirse, mahalle bazında katılımın bir önceki referanduma göre çok fazla olduğu görülmektedir. İktidarın ve muhalefetin bu seçimleri Türkiye için çok kritik olduğunu, seçmene anlatmasının bu oranın yükselmesine etkisi olduğu söylenebilir. Bununla birlikte seçimin yapıldığı dönem itibariyle bir önceki referanduma göre mahallenin seçmen sayısında ciddi bir artış olduğu görülmektedir. 2010 yılında yapılan son seçimlerde 11 bin civarında olan seçmen sayısı 2017'de 17 bin civarına yaklaşmıştır. Bu artışın kapalı konut sitesinin bitmesi ve insanların toplu olarak 
yerleşmeye başladığını göstermektedir. Dolayısıyla bu yerleşme seçmen sayısında ciddi bir artışa neden olmaya başlamış ve seçim sonuçlarına etki etmeye başlamıştır. İki seçim arasındaki sonuçlar karşılaştırıldığında bölgedeki oy artışının "hayır” oyları üzerinde ciddi artışa neden olduğu görülmektedir.

Bir sonraki seçim ise 2014 ve 2018 yılında yapılan cumhurbaşkanlığ seçimleridir. 2014 seçiminde bir önceki referanduma ve yapılan genel, yerel seçimlere göre katılım oranının daha düşük olduğu görülmektedir.

Tablo 5. Site Öncesi ve Sonrası Cumhurbaşkanlığı Seçim Sonuçları

\begin{tabular}{|c|c|c|c|c|c|c|c|c|c|c|}
\hline $\begin{array}{l}\text { CB. Seçimi ve } \\
\text { Referandumlar }\end{array}$ & $\begin{array}{l}\text { Seçmen } \\
\text { S. }\end{array}$ & $\begin{array}{l}\text { Seçime } \\
\text { K.S.S }\end{array}$ & $\begin{array}{l}\text { Katilim } \\
\text { Oramı }\end{array}$ & $\begin{array}{l}\text { R.T. } \\
\text { Erdoğan }\end{array}$ & E.jhsanoğhn & S.Demirtas & $\begin{array}{l}\mathbf{M} \\
\text { İnce }\end{array}$ & $\begin{array}{l}\text { M. } \\
\text { Aksener }\end{array}$ & $\begin{array}{l}\text { T. } \\
\text { Karamanoğlu }\end{array}$ & $\begin{array}{l}\text { D. } \\
\text { Perincek }\end{array}$ \\
\hline $\begin{array}{l}\text { 12. CB. Seçimi } \\
(2014)\end{array}$ & 11128 & 7827 & $\% 70.34$ & 5430 & 2040 & 193 & - & - & - & - \\
\hline $\begin{array}{l}\text { 13. CB. Seçimi } \\
\text { (2018) }\end{array}$ & 17470 & 15360 & $\% 87.92$ & 8487 & - & 322 & 5140 & 930 & 210 & 29 \\
\hline
\end{tabular}

AK Parti'nin adayının genel başkan ve başbakan Recep Tayyip Erdoğan olduğu cumhurbaşkanlığı seçimlerinde CHP ve MHP ortak aday olarak Ekmeleddin İhsanoğlu'nu göstermişlerdir. HDP’nin eş-genel başkanı Selahattin Demirtaş ise üçüncü aday olarak cumhurbaşkanlığı seçimine girmiştir. Bölgenin seçim sonuçlarına bakıldığında Erdoğan'ın \%70 i aşan bir oy aldığı görülmektedir. Ortak aday İhsanoğlu'nun ise \%27 civarında bir oy almıştır. Demirtaş ise çok düşük oranda kalmıştır. Süreç içerisinde diğer bir seçim ise, 24 Haziran 2018 genel seçimleri ile birlikte yapılan cumhurbaşkanlığı seçimleridir. İkinci kez halk tarafından seçilen cumhurbaşkanlığı seçiminin 2014 yılındaki cumhurbaşkanlığı seçiminden farkı aynı zamanda yeni sistem olan cumhurbaşkanlığı hükümet sisteminin ilk cumhurbaşkanı seçilmiştir. 2014 yılında halkoyuyla seçilmesine rağmen parlamenter sistem devam etmiştir. 2018'de ise, yasal değişiklik ile partilerin seçimler öncesi ittifak yapabilmesinin önü açılmıştır. Bu bağlamda Cumhur İttifak'ı tek adayla seçime girerken, Millet İttifak'1 ve HDP cumhurbaşkanlığı konusunda mutabakat sağlayamamış, dört farklı aday ile seçimlere girmişlerdir. Seçim sonucuna bakıldığında bir önceki seçime göre \%15'e yakın oy kaybetmesine rağmen Erdoğan yine cumhurbaşkanı seçilmiştir. Bu noktada iki seçim arasında seçmen sayısındaki artış ile birlikte oy dengesinin yine değiştiği gözlemlenmektedir. Bu da bölgedeki sitelere yerleşimin 2017 sonrasında tamamlanmış olması ile açılanabilir.

Mahalle bazlı sonuçlara bakıldığında Erdoğan'ın Türkiye genelinden (\%52) daha fazla oy aldığı görülmektedir. MHP'nin aday çıkarmamış olması Erdoğan'ın genel seçimlerden daha fazla oy almasını sağlamıştır. Öte yandan CHP'nin adayı İnce, yine partisinin genel seçimlerdeki oyundan daha fazla oy almıştır. Bölgesel bazlı ilk defa \%30’ların üzerine çıkmıştır. 
Cumhurbaşkanlığı seçimlerinde adayların büyük etkisinin olduğunu söylemek mümkündür. Ancak kapalı konutların getirdiği artış ile birlikte de özellikle CHP'nin bu seçimlerde de mahalle bazında önceki seçimlere oranla daha yüksek oy aldığı görülmektedir. Bütün bunlara ek olarak bir önceki cumhurbaşkanlığına mahalle bazında katılım \%70 iken, 2018 seçimlerinde katılım \%87 civarında olmuştur. Bunda seçimin genel seçimler ile birlikte yapılmasının etkisinin olduğu söylenebilir.

Kapalı toplu konutlardan önceki geriye dönük incelenen toplam yedi seçim genel olarak değerlendirildiğinde, bölgenin seçmen davranışının sağ ve daha çok muhafazakâr çizgide olduğu görülmektedir. AK Parti ile konsolide olmuş bir seçmen grubunun olduğu ve bunun uzun yıllar değişmediği görülmektedir. Ülkenin siyasal ve ekonomik gelişmelerinin de bölgenin seçmeninin tercihini değiştirmediği görülmektedir. CHP'nin ise, ülkenin genelinde olduğu gibi belirtilen yıllar içerisinde bölgede doğal bir sınıra çarptığı ve seçimlerde bu sınırı geçemediği görülmektedir. Daha ideolojik partiler olan MHP, SP ve HDP'nin ise, bölgede çok düşük oranda kaldıkları görülmektedir.

\section{Kapalı Konutlardan Sonraki Seçim Sonuçları ve Analizi}

Tuzla/Aydıntepe mahallesinde yükselen kapalı konut sitesi olan Evora'da 4 binden fazla konut ile 15 bin kişilik yeni bir yaşam alanı oluşturulmuştur. Sosyolojik ve demografik olarak bulunduğu bölgeden bir duvarla ayrışan bu konut alanı aynı zamanda oy verme davranışında da yine farklılığı ortaya koymaktadır. Genellikle ekonomik gelir düzeyi yüksek olan (beyaz yakalı) kişilerin yaşadığı bu alan güvenlik, statü, sosyal imkânlar, benzer sosyo-ekonomik düzeydeki insanlar ile bir arada yaşama isteği gibi nedenler ile tercih edilmektedir. 2015 yılından itibaren yapımı tamamlanan kapalı konut alanı hızlı bir şekilde dolmaya başlamıştır. Bu hızlı nüfus artışı konutlar tamamlandıktan sonra yapılan ilk seçimlerdeki seçmen sayısındaki artış ile açık bir şekilde görülmektedir.

Tablo 6. Site Sonrası Yapılan Seçimlerin Sonuçları

\begin{tabular}{|c|c|c|c|c|c|c|c|c|c|}
\hline Seçimler & $\begin{array}{l}\text { Seçmen } \\
\text { Sayısı }\end{array}$ & $\begin{array}{l}\text { Seçime } \\
\text { Katılan S.S }\end{array}$ & $\begin{array}{l}\text { Katılım } \\
\text { Oranı }\end{array}$ & $\begin{array}{l}\text { AK } \\
\text { Parti }\end{array}$ & CHP & MHP & HDP & SP & $\begin{array}{l}\text { Iyi } \\
\text { Parti }\end{array}$ \\
\hline $\begin{array}{l}\text { 24 Haziran MV } \\
(24.06 .2018)\end{array}$ & 17470 & 15357 & $\% 87.90$ & $\begin{array}{c}6909 \\
(\% 46)\end{array}$ & $\begin{array}{c}3689 \\
(\% 25)\end{array}$ & $\begin{array}{c}1633 \\
(\% 11)\end{array}$ & $\begin{array}{c}810 \\
(\% 5)\end{array}$ & $\begin{array}{c}332 \\
(\% 2)\end{array}$ & $\begin{array}{r}1559 \\
(\% 11)\end{array}$ \\
\hline $\begin{array}{l}\text { Tuzla B. B. } \\
\text { (31 Mart 2019) }\end{array}$ & 17636 & 14497 & $\% 82.20$ & $\begin{array}{c}7502 \\
(\% 54)\end{array}$ & $\begin{array}{l}5976 \\
(\% 43)\end{array}$ & - & - & $\begin{array}{l}357 \\
(\% 3)\end{array}$ & - \\
\hline $\begin{array}{l}\text { İBB } \\
\text { (31 Mart 2019) }\end{array}$ & 17636 & 14509 & $\% 82.27$ & $\begin{array}{l}7528 \\
(\% 54)\end{array}$ & $\begin{array}{l}6123 \\
(\% 44)\end{array}$ & - & - & $\begin{array}{l}237 \\
(\% 2)\end{array}$ & - \\
\hline $\begin{array}{l}\text { IBB Yenilenen } \\
\text { Seçimler } \\
\text { (23 Haziran 2019) }\end{array}$ & 17636 & 14802 & $\% 83.93$ & $\begin{array}{l}7273 \\
(\% 50)\end{array}$ & $\begin{array}{c}7079 \\
(\% 49)\end{array}$ & - & - & $\begin{array}{l}136 \\
(\% 1)\end{array}$ & - \\
\hline
\end{tabular}


Tablo 6 incelendiğinde seçmen sayısının 2015 seçimlerindeki verilere göre yaklaşık 4 bin arttığı görülmektedir. Bu artış mahallenin doğal artışı dışında gerçekleşen ve 3 yıl içerisinde tamamlanan kapalı konutlara yerleşimin başlaması ile ilişkilidir. Partisel bazda incelendiğinde iktidar partisinin oyunun bir önceki genel seçimlere oranla düştüğü ancak bu düşüşün sonucu etkileme anlamında yüksek olmadığı söylenebilir. Yani kapalı konut alanları ile bir anda artan nüfusun AK Parti'de bir artışa neden olmamıştır. Öte yandan CHP’nin oy oranında ciddi bir artı̧̧ın olduğu görülmektedir. Bir önceki genel seçimlerde yaklaşık 2500 oy alan partinin kapalı konutlar tamamlandıktan sonra oyunun 3600'ün üzerine çıktığı görülmektedir. Bu noktada vurgulanması gereken noktalardan bir tanesi CHP’nin oyundaki artışın iktidar partisi olan partiye bir tepki ya da iktidarın yıpranma payından kaynaklanmamaktadır. Çünkü belirtildiği üzere AK Parti'nin oyunda ciddi bir düşüş yaşanmamış, büyük oranda oyunu konsolide etmiştir. Bir önceki seçime oranla kaybettiği seçmenin de daha çok MHP’ni tercih ettiğini partinin oy miktarındaki artıştan görülmektedir.

Yerel seçimlere bakıldığında ise, öncelikli olarak birçok faktörün bu seçimlerde etkili olduğunu söylemek gerekir. Türkiye'de yerel seçimlerin son dönemlerde daha merkezileştiği, adaydan çok partinin genel merkezlerinin ve genel başkanlarının yürüttüğü kampanyalar olduğu görülmektedir. Bölgesel anlamda ise öncelikli olarak Tuzla Belediyesi'nin uzun yıllardır AK Parti tarafından kazanıldığını belirtmek gerekir. 2019 yılındaki seçim sonuçlarına bakıldığında ise, bir önceki yerel seçimlere göre iki büyük partinin de oyunu arttırdığı görülmektedir. Bu artışın ittifakların getirdiği ve ittifak içerisindeki partilerin tek adayla seçime girmesinden kaynakladığı söylenebilir. Özellikle Cumhur ittifakının (AK Parti-MHP- BBP) tek bir adayla ilçe belediye başkanlığı seçimine girmiş olması bu artışı açıklayabilir. Diğer taraftan ise yine ittifak olarak Millet ittifakının (ve aday çıkarmayarak dişarıdan destek olarak HDP) CHP adayı İmamoğlu'nu desteklemesi bu artışı açıklamakta yeterli değildir. Çünkü mahalle bazında genel seçim ve yerel seçim sonuçları incelendiğinde kapalı konutlardan öncesinde ve sonrasında CHP dişındaki ittifak partilerinin oy miktarlarının artış ile aynı miktarda olmadığı görülmektedir. Dolayısıyla yerel anlamda da kapalı konutların getirdiği nüfus artışının CHP’nin ilçe belediye başkanlığındaki oy oranını bir önceki yerel seçimlere göre neredeyse \%100 oranında arttırmıştır.

$\mathrm{Bu}$ artış kapalı konutların seçmenlere sağladığı imkânlar ile birlikte yerel hizmetlere çok fazla ihtiyacının kalmaması ile birlikte yerel hizmetleri değerlendirmeden daha çok merkezi seçim gibi ideolojik bir tercihte bulundukları yorumu yapılabilir. Çünkü çalışmanın konusu olan ve bunun gibi birçok sitede yerel yönetimin temel görevleri olan temizlik, su, elektrik, gaz, çöp, aydınlatma vs. gibi birçok hizmet site içerisinden belirli aidat karşılığında sağlanmaktadır. 
Dolayısıyla kapalı konutta yaşayan seçmenlerin yerel hizmete çok fazla ihtiyacı olmamaktadır. Öte yandan kapalı olan bu sitelere seçim dönemlerinde seçim kampanyası yapabilmek için girmek güvenlik engeli nedeniyle oldukça zordur. Aynı zamanda yine mahalle kültürü içerisinde seçimlerde etkili olan hemşeri dernekleri, camii dernekleri gibi kuruluşların da bu bölgelerde etkisi zayıftır.

Büyükşehir belediye başkanlığı seçiminde ise, AK Parti'nin oyunu yine konsolide ettiği ve aynı oranda oy aldığı görülmektedir. Ancak CHP’nin yine kapalı konutların getirdiği nüfus artışının yansıması görülmektedir. Bir önceki yerel seçimlerde 2500 civarında oy alan parti kapalı konutların tamamlanmasından ardından bölgedeki oy sayısını 6000'in üzerine çıkarmıştır. Bu noktada özellikle İBB seçimlerinde parti kampanyası ve aday etkili olmuştur. Bütün bu değişimler İstanbul geneline yansımasıyla birlikte 25 yıl aradan sonra büyükşehir belediyesinin değişmesine neden olmuştur. Yenilenen İBB seçimlerinde ise yine iki partinin büyük oranda oyunu koruduğu, AK Partinin 300 oy kaybının CHP lehinde 600 oyluk bir yansımasının olduğu söylenebilir. Bununla birlikte yenilenen seçimlerde \%1.7'lik bir katılım artışı görülmektedir. Bunun hangi parti lehinde olduğunu ölçmek zor olsa da mahalle bazındaki seçimlerin yenilenmesine çok küçük tepki gösterilse de İstanbul genelinde bu tepki daha büyük olmuş ve CHP belediye başkanlığını tekrar kazanmıştır.

Aşağıda Tablo 7 ve Tablo 8'de sırasıyla 2019 seçimleri için Aydıntepe mahalle seçmeninin tercihi ile aynı mahallede yer alan kapalı konut seçmeninin tercihlerini karşılaştırmakta ve çalışmanın argümanını desteklemektedir. ${ }^{1}$

Tablo 7. 2019 Yerel Seçimlerinde (Tuzla Belediye Başkanlığı) Sadece Mahalle Seçmeninin Oy Kullandığı Bazı Sandıkların Sonuçları

\begin{tabular}{lllllllll}
\hline & $\begin{array}{l}\text { Toplam } \\
\text { Geçerli }\end{array}$ & & & VATAN & & AK & \\
Sandik No & Oy & SP & BTP & PARTISI & BBP & CHP & PARTI & DSP \\
\hline 1134 & 285 & 9 & 0 & 1 & 0 & 100 & 174 & 1 \\
1135 & 288 & 13 & 0 & 0 & 5 & 93 & 175 & 2 \\
1136 & 270 & 13 & 0 & 1 & 4 & 69 & 183 & 0 \\
1137 & 276 & 7 & 0 & 0 & 3 & 74 & 191 & 1 \\
1138 & 283 & 10 & 0 & 1 & 2 & 86 & 183 & 1 \\
1139 & 268 & 12 & 1 & 0 & 7 & 89 & 158 & 1 \\
1140 & 262 & 11 & 0 & 1 & 2 & 63 & 184 & 1 \\
1141 & 287 & 7 & 0 & 1 & 3 & 90 & 185 & 1 \\
1142 & 281 & 7 & 0 & 0 & 3 & 82 & 187 & 2 \\
1143 & 283 & 8 & 0 & 0 & 8 & 80 & 184 & 3 \\
Toplam & 2783 & 97 & 1 & 5 & 37 & 826 & 1804 & 13 \\
\hline
\end{tabular}

Kaynak: www.ysk.gov.tr

12019 Yerel Seçimlerinde Aydıntepe Mah. Kurulan sandıkların numaralarına göre 1149 ile 1177 arasındakilerin kapalı-konut sitesinin (Evora) seçmeninin yoğun olduğu bilgisine parti teşkilatları ile yapılan görüşme sonucunda ulaşı ımıştır Bu sandıklarda sadece site seçmeni oy kullanmamıştır. Ancak tüm site seçmeni bu sandıklara dağıtılarak oy kullandırılmıştır 
Tablo 7'deki verilere bakıldığında sadece mahalle seçmeninin olduğu ve 2019 yılında yapılan yerel seçimlerde Tuzla Belediye Başkanlığı oylamasının on sandık sonucuna yerel verilmiştir. Belirtildiği gibi edinilen bilgiye göre bu sandıklarda toplu konutta yaşayan seçmenin bulunmadığı bilinmektedir. Sonuçlara bakıldığında mahalle seçmeninin büyük oranda hem parti olarak hem yerel hizmet olarak AK Parti'yi tercih ettiği görülmekte ve bu partinin CHP'nin iki katından daha fazla oy aldığı seçilen örnek sandıklarda görülmektedir. Bölgenin diğer sandıklarına da bakıldığında benzer sonuç ortaya çıkmıştır.

Tablo 8. 2019 Yerel Seçimlerinde (Tuzla Belediye Başkanlığı) Kapalı Konut Seçmeninin Yoğun Olduğu Bazı Sandık Sonuçları

\begin{tabular}{lllllllll}
\hline Sandk No & $\begin{array}{l}\text { Toplam } \\
\text { Geçerli } \\
\text { Oy }\end{array}$ & SP & BTP & $\begin{array}{l}\text { VATAN } \\
\text { PARTísi }\end{array}$ & BBP & CHP & $\begin{array}{l}\text { AK } \\
\text { PARTí }\end{array}$ & DSP \\
\hline 1149 & 241 & 3 & 0 & 0 & 4 & 115 & 118 & 1 \\
1150 & 266 & 6 & 0 & 0 & 1 & 117 & 139 & 3 \\
1151 & 259 & 10 & 0 & 0 & 5 & 152 & 92 & 0 \\
1152 & 275 & 5 & 0 & 1 & 0 & 143 & 126 & 0 \\
1153 & 271 & 5 & 0 & 0 & 0 & 160 & 105 & 1 \\
1154 & 279 & 9 & 0 & 0 & 4 & 157 & 106 & 3 \\
1155 & 281 & 8 & 0 & 1 & 3 & 159 & 110 & 0 \\
1156 & 271 & 6 & 0 & 0 & 0 & 160 & 103 & 2 \\
1157 & 262 & 4 & 0 & 0 & 4 & 162 & 91 & 1 \\
1158 & 274 & 1 & 0 & 1 & 4 & 162 & 105 & 1 \\
Toplam & $\mathbf{2 6 7 9}$ & $\mathbf{5 7}$ & $\mathbf{0}$ & $\mathbf{3}$ & $\mathbf{2 5}$ & $\mathbf{1 4 8 7}$ & $\mathbf{1 0 9 5}$ & $\mathbf{1 2}$ \\
\hline
\end{tabular}

Kaynak: www.ysk.gov.tr

Tablo 8'de örnek verilen sandıklar 2019 yerel seçimlerinde Tuzla Belediye Başkanlığı oylamasının sonucunda seçilen on sandık gösterilmektedir. Bu sandıklarda bulunan seçmen profili ise tamamen değil, ama daha çok kapalı konutta yaşayan seçmenlerden oluşmaktadır. Tablo 8'deki sonuçlara bakıld1ğında benzer bölgede, benzer adaylara karşı sonucun büyük oranda farklılaştığı gözlemlenmektedir. Uzun yıllar AK Parti'nin yerel yönetiminde bulunan ilçede seçilen on sandıkta, iktidar partisinin ana muhalefet partisinden yaklaşık 400 oy geride olduğu görülmektedir. CHP’nin ise sadece mahalle seçmeninin olduğu sandıklardan 800 oy alırken, Evora seçmeninin yoğun olduğu on sandıkta 1487 oy almıştır. Bu sonuç kapalı konutta yaşayan seçmenin yoğun olduğu diğer 28 sandıkta da benzer şekildedir. Daha önce de belirtildiği gibi içerisinde parti propagandasının yapılamadığı, aday tanıtımlarının çok fazla yer almadığı aynı zamanda yerel hizmetleri kendi içinde tamamlayan 
kapalı-konut sitesi sakinlerinin oy tercihlerinde adaydan, hizmetten çok bir parti yönelimi içerisinde olduğu söylenebilir.

Siteler kurulmadan önceki Türkiye genelinde genel ve yerel seçimlerde (2011-2017) AK Parti’nin aldığı oy oranları baz alındığında \%40 ile \%50 arasında olduğu görülmektedir Aynı dönemde mahalle bazında bakıldığında ise, oyların \%60'ların üzerinde olduğu görülmektedir. ${ }^{2}$ CHP ise, aynı dönemde Türkiye genelinde \%25'ler civarında oy alırken, mahalle bazında bu oranın \%15’lere düştüğü görülmektedir. Kapalı site sonrası yapılan 2018 genel seçimine bakıldığında genel seçimlerde Türkiye genelinde Cumhur İttifakı'nın (AK Parti-MHP-BBP) toplamda $\% 53,66^{3}$ oy aldığı görülürken, aynı seçimlerin mahalle bazında sonucu ise, bu oranın $\% 57^{4}$ civarında olduğu görülmektedir. Millet İttifak'ının (CHP-İyi Parti- SP) ise, aynı seçimlerde Türkiye genelinde \% 33,94 oy alırken, kapalı konut sitesinin tamamlandığı mahallede $\% 38^{5}$ oy almıştır. Yerel seçimlerde kapalı konut sitelerinin etkisi daha belirgin hale gelmiştir. Kapalı konutlara yerleşimin hızla artması ile birlikte mahallenin 2019 yılındaki yerel seçimlerdeki mahalle bazındaki sonuçlara bakıldığında AK Parti'nin Tuzla belediye başkanlığı seçimlerinde \% 54, CHP'nin ise \% 43 oy aldığı görülmektedir. Bu oranlar büyükşehirde ise, sırasıyla \%54 ve \% 44 olmuştur. Türkiye genelinde yerel seçim sonuçlarına bakıldığında, Cumhur İttifak'ının oyu \% 51,64 olurken, Millet İttifak'ının oyu \% 37,57 olmuştur. Yenilenen İBB seçimlerinde İstanbul genelinde belediye başkanlığını kazanan CHP'nin adayı Ekrem İmamoğlu olmuş, bu seçimde mahalle sonuçlarında ise, AK Parti \%50, CHP \% 49 oy almıştır (Seçimhaber, 2020, YSK, 2020). Dolayısıyla kapalı konut siteleri bölgede henüz yapılmamışken mahallede CHP'nin oyları Türkiye genelinden düşükken AK Parti’nin oyları ise ortalamanın üstündedir. Bu çalışma göstermiştir ki sitelerin yapılması ile birlikte demografik yapının değişmesi ve seçmen profilinde bölgede yaşanan değişiklik sonucunda AK Parti Türkiye geneline benzer oylar almaya devam ederken, CHP bölgede Türkiye genelinin üzerinde oy almayı başarmıştır. Kapalı konut seçmenleri yerleşilen bölgede merkez partilerin oylarının artmasında etkili olmuştur.

2 Diğer partilerden MHP, Türkiye genelinde \%10 ile \%16 arasında bir bantta yer alırken, mahalle bazında da benzer oranlarda oy almaktadır. HDP'nin ise, Türkiye genelinde baraj sorunu yaşamadığı görülürken, mahalle bazında sadece \%4 civarında sonuçlar elde ettiği görülmektedir.

3 Bu oranın \%42,56'sının AK Parti, \%11,10 ise MHP oyu olarak sonuçlara yansımıştır.

4 Bu oranın \%46'sı AK Parti oyu olarak sonuçlara yansımıştır.

5 CHP \%25 oy oranı ile Türkiye genelinde aldığı \%22'lik oyu ilk defa mahallede geçmiştir. Mahalledeki sonuçlara göre diğer partilerin oy oranları ise, lyyi parti \%1 1, SP \%2, tek başına giren HDP ise, \%5' tir. 


\section{Sonuç}

Sosyal sınıf kavramı, sosyolojik olarak daha çok ekonomik anlamıyla birlikte kullanılmaktadır, siyaset bilimi literatüründe ise seçmenlerin meslekleri, gelir durumu ve de eğitim durumu üzerinden değerlendirilmektedir Ekonomik olarak bir zümreye, bir insan topluluğuna ait olma şeklinde ifade edilebilmektedir. Batı'daki sınıflara bakıldığında bir mücadelenin ürünü olarak oluşmuşken, Türkiye'de bu durumun daha çok devlet ve kurucu iktidar tarafından oluşturulduğu görülmektedir. Batı'daki gibi bir burjuva sınıfının olmadığı, kazanılan hakların bir mücadele sonucunda olmadığı ve kurucu iktidar tarafından birçok hakkın verildiği görülmektedir. Ekonomik olarak da yine sermayenin belirli gruplara dağıtıldığı görülmektedir. Bir devlet geleneği olarak gelişen bu durum tüm iktidarlarda neredeyse benzer olmuş, her iktidar kendi sermaye gruplarını oluşturmuştur. Dolayısıyla kendiliğinden oluşan bir sınıfsal yapı yerine daha çok iktidar ve çevresinde şekillenen sermayedarlar ile orta-alt sınıf toplumsal yapı içerisinde belirgin hale gelmiştir.

İktidar ve etrafını merkez olarak niteleyen Mardin, bunun dışında kalanı ise, çevre olarak adlandırmış ve hem sosyolojik olarak hem de siyasal olarak bu merkez-çevre ilişkisinin önemli olduğunu vurgulamıştır. Cumhuriyet ile birlikte gelişen yeni ülkenin merkez kanadında uzun süre CHP ve elitler olurken, çevrede ise, daha çok merkezden uzaklaştırılmış muhafazakâr, dindar ve ekonomik olarak düşük gruplar bulunmuştur. Merkezde bulunan elitler daha eğitimli ve sol görüşe yakın olurken, çevre, belirtildiği gibi daha az eğitimli, sağ görüşe ve dindar partileri tercih etmişlerdir. Son yıllarda ise bu durumun ekonomik ve bölgesel olarak değiştiğini söylemek mümkündür. Bu değişimin başında ise, çevrenin yanı kırsalın 1980'lerden itibaren kentlere gelmesiyle birlikte demografik yapıların değişmesi gelmektedir. Dolayısıyla şehirlerin homojen yapısı daha karmaşık hale gelmiştir. Bu kentlerin sosyolojik olarak değişmesini getirdiği gibi kentlerde seçim sonuçlarında da değişikliğe neden olmuştur. Örneğin uzun yıllar merkezden yani iktidardan uzak kalan muhafazakâr ya da İslamcı parti olan Refah Partisi 1994 yılında İstanbul Büyükşehir Belediyesini kazanmış ve yaklaşık 25 yıl elinde bulundurmuştur. Bu çalışmada 25 yıl sonra 2019'da belediyelerin el değiştirmesine yönelik birçok neden tartışılmıştır, kapalı-konut siteleri ve sınıfsal oy verme seçim sonuçlarına etki eden parametrelerden biri olarak ele alınmıştır.

Kapalı-konut siteleri bir sosyal sınıf, zümre olarak değerlendirilmelidir. Ekonomik olarak ve sosyal yaşam olarak birbirine benzer insan gruplarının bir arada yaşadıkları yerler olan bu siteler aynı zamanda bulundukları bölgelerin sosyolojik yapısıyla beraber siyasal, ideolojik durumunu da 
etkilemektedir. Mekânsal ve bölgesel oy verme faktöründe olduğu -ki bu siteler de neredeyse bir ilçe hatta kırdaki bir ile yakın büyüklükte olduğu düşünüldüğünde bir bölge olarak değerlendirilebilir- gibi buralarında belirli ideolojik tercihlerinin olduğu veya zamanla oluştuğu görülmektedir. Ekonomik, sosyal, kültürel gibi birçok faktörle bir arada yaşayan insanlar oy verirken de benzer tercihlerde bulunma eğilimi göstermektedirler. Dolayısıyla bu kapalı konutların oy tercihleri incelendiğinde, tıpkı bir bölge gibi sonuçlar ortaya çlkmakta ve insanların benzer tercihlerde bulunduğu görülmektedir. Dünya Değerler Anketinin yaptığı anket sonuçlarına göre 2007'den 2018 senesine, yani son 10 yılda üst sınıf katılımcıların CHP'yi tercih etme oranı iki katına çıkmıştır. AK Parti ise, üst sınıfta oy kaybederken, en çok işçi sınıfı ve alt sınıf tarafından tercih edilmektedir.

Nitekim Tuzla Evora konutlarının bulunduğu mahalle olan Aydıntepe mahallesinin site öncesi ve sonrası seçim sonuçları incelendiğinde, yaşanan değişim tablo ve grafiklerde açık bir şekilde görülmektedir. Bir anda hızlı artan seçmen sayısı ile CHP’nin oylarında bölgede hiç olmadığı kadar artış gözlenmektedir. Yine 2018 genel seçimlerinde iktidar bloğunun kaybettiği oyların en çok İYİ Parti'ye kaydığı dikkat çekicidir. Diğer partilerin oylarında anlamlı bir artış veya azalış olmadığı; ancak yeni yerleşim yerine gelen seçmenin muhalefet partilerine büyük oranda oy verdiği görülmektedir. Bu durum yapılan kapalı konut siteleri ile birlikte kitlesel olarak gelen seçmenin belli bir tarafa yöneldiğini göstermektedir. Mahalle seçmeninin sayısı büyük oranda değişmediğinden dolayı AK Parti bir önceki seçimlerle aynı oyunu korurken, nüfus artışı ile birlikte CHP yeni gelen seçmenin neredeyse tamamının oyunu aldığı için bölgede AK Parti ile yarışır hale gelmiştir. Sonuç olarak büyükşehirlerde başlayan kentsel dönüşüm ile birlikte hızla artmaya başlayan kapalı konut sitelerinin yer aldıkları bölgelerdeki oy tercihlerini ve seçmenlerin ideolojik yönelimlerini değiştirdiği incelenen seçimler ile bu çalışmada görülmüştür. 


\section{Kaynakça}

Akgün, Birol. (2014), Türkiye'de Seçmen Davranışı: Partizan Tutumlar, İdeoloji ve Ekonomik Faktörlerin Oy Vermeye Etkisi. Selçuk Üniversitesi Sosyal Bilimler Meslek Yüksekokulu Dergisi,1 (4), 75-92.

Baycan, Tuzin., Akgün, Aliye Ahu. (2012), "Gated Communities in Istanbul: The New Walls Of The City" The Town Planning Review, vol. 83. no.1, 87-109.

Best, Robin E. (2011), The declining electoral relevance of traditional cleavage groups. European Political Science Review, 3(2), 279-300.

Blakely, Edward J., Snyder, Mary Gail. (1997), Fortress America, Gated Communities in The United States Washington, D.C: Brookings Institution Press.

Bora, Tanıl. (2017), Cereyanlar: Türkiye'de Siyasi İdeolojiler. İstanbul: İletişim Yayınları.

Calderia, Teresa P.R. (1996), "Fortified Enclaves: The New Urban Segregation”. Public Culture, vol. 8, 303-328.

Candan, Ayfer Bartu., Özbay, Cenk. (2014), Yeni İstanbul Çalışmaları. İstanbul: Metis Yayınları.

Clark, Terry Nicholas and Lipset, Seymour Martin (eds.) (2001), The Breakdown of Class Politics: A Debate on Post-Industrial Stratification. Boulder, CO: Westview Press.

Çarkoğlu, Ali. (1998), "The Turkish Party System in Transition: Party Performance an Agenda Transformation," Political Studies, 46:3, 544-571.

Çarkoğlu, Ali., Avcı, Gamze. (2002), "An Analysis of the Electorate from a Geographical Perspective" in Yılmaz Esmer and Sabri Sayarı (eds.) Politics, Parties and Elections, Lynn Rienner, 115-136.

Çarkoğlu, Ali. (2012), “Voting Behavior in Turkey”, in Heper M. and S. Sayarı (eds.) Handbook of Modern Turkey, Routledge, 160-170.

Çarkoğlu, Ali. (2012), "Economic evaluations vs. ideology: Diagnosing the sources of electoral change in Turkey, 2002-2011", Electoral Studies, vol. 31, 513-521.

Çinko, Levent. (2006), "Seçmen Davranışları ile Ekonomik Performans Arasındaki Ilișkilerin Teorik Temelleri ve Türkiye Üzerine Genel Bir Değerlendirme”. Ankara Üniversitesi SBF Dergisi, 103-116.

Dalton, Russell J. (2008), Citizen Politics: Public Opinion and Political Parties in Advanced Industrial Democracies. (5th edition). Chatham, NJ: Chatham House Publishers.

Debus, Marc Stegmaier, Mary, and Tosun, Jale (2014), “Economic Voting under Coalition Governments: Evidence from Germany", Political Science Research and Methods, 2, 49-67.

Dikici-Bilgin, Hasret. (2018), "Social Conflicts and Politicised Cleavages in Turkey", içinde Party Politics in Turkey: A Comparative Perspective, Sabri Sayarı, P. Ayan Musil ve Özhan Demirkol (der.). Londra, New York: Routledge, 179-195.

Ergüder, Üstün. (1980), Türkiye'de Değişen Seçmen Davranışları Örüntüleri, s.285, orjinali "Changing Patterns ol Elecloral Behavior in Turkey". Boğaziçi Üniversitesi Dergisi, Sosyal Bilimler, Cilt B-9. 19 80-81, 45-69.

Erghder, Üstün. (1988), "Post-1980 Parties and Politics in Turkey," in Perspectives on Democracy in Turkey, ed. Ergun Özbudun. Ankara: Turkish Political Science Association Publicati-nons

Evans, Geoffrey. (1999), The End of Class Politics? Class Voting in Comparative Context. Oxford: Oxford University Press.

Evans, Geoffrey., and Tilley, James. (2012), "How Parties Shape Class Politics: Explaining the Decline of the Class Basis of Party Support." British Journal of Political Science, 42: 137-161. 
Franklin, Mark N., Mackie, Thomas, T., and Valen, Henry. (1992), Electoral Change: Responses to Evolving Social and Attitudinal Structures in Western Nations. Cambridge: Cambridge University Press.

Garreau, Joel. (1991), Edge City: Life on the New Frontier, Doubleday, New York.

Giddens, Anthony. (2012), Sosyoloji. İstanbul: Kırmızı Yayınları.

Glasze, Georg. (2003), "Some Reflections on the Economic and Political Organisation of Private Neighbourhoods", International Gated Communities Conference: Building Social Division or Safer Communities 18-19 September 2003, University of Glasgow, 1-13.

Grusky, David B. (2008), Social Stratification: Class, Race and Gender in Sociological Perspective (Third Edition). Colorado: Westview Press.

Heper, Metin. (1985) The State Tradition in Turkey. Beverley: The Eothen Press,

Inglehart, Ronald and Norris, Pippa (2019), Cultural Backlash: Trump, Brexit, and Authoritarian Populism, Cambridge University Press.

Kennedy, David J. (1995), "Residential Associations as State Actors: Regulating the Impact of Gated Communities on Nonmembers", The Yale Law Journal, vol.105/3.

Keyder, Çağlar. (2014), Türkiye'de Devlet ve Sınıflar. İstanbul: İletişim Yayınları.

Knutsen, Oddbjørn. (2006), Class Voting in Western Europe - A Comparative Longitudinal Study. Lanham: Lexington Books.

Lipset, , Seymour Martin. (1959), “Democracy and Working-Class Authoritarianism”, American Sociological Review, 24: 482-501.

Mardin, Şerif. (1990), Türkiye’de Toplum ve Siyaset. İstanbul: İletişim Yayınları.

Oesch, Daniel. (2006), 'Coming to grips with a changing class structure: an analysis of employment stratification in Britain, Germany, Sweden and Switzerland', International Sociology, 21: 263-288.

Powell, G. Bingham, Jr. and Whitten, Guy D. (1993), "A Cross-National Analysis of Economic Voting: Taking Account of the Political Context", American Journal of Political Science, 37 (1993), 391-414.

Seçim Haber (2020). Seçim sonuçları. Erişim Adresi: https://secim.haberler.com/ Erişim Tarihi: 02.01.2020.

Sipahi, Tunç, (2014) “Rasyonel” Seçmenler Solu Seçer mi? Seçmen Davranışı ve Sol, Gelenek, sayı. 123.

Tachau, Frank. (2002), "An Overview of Electoral Behavior: Toward Protest or Consolidation of Democracy?", at Sayari \& Esmer, Politics, Parties and Elections in Turkey

Taşkın, Burcu. (2015), Voter Turnout in Turkey's Parliamentary and Local Elections (1950-2014): Does Participation Increase when Competition Decreases?, Turkish Studies, 16:4, 465-486.

Whitten Guy D., Palmer, Harvey D. (1999), "Cross National Analyses of Economic Voting." Electoral Studies, Vol. 18, 49-67.

Yakışan, Duygu. (2008), Postmodern Planlamanın Bir Yansıması Olarak Kapılı- Güvenlikli Siteler ve Konya Örneğinde Bir Araştırma, Yayınlanmamış Yüksek Lisans Tezi, Selçuk Üniversitesi, Konya.

YSK (2019 ). Seçim Sonuçları. Erişim Adresi: https://sonuc.ysk.gov.tr/sorgu Erişim Tarihi: 20.11.2019.

YSK (2020), Seçim Sonuçları. Erişim Adresi: https://sonuc.ysk.gov.tr/sorgu Erişim Tarihi: 02.01.2020. 